JERZY SŁYK

Uniwersytet Kardynała Stefana Wyszyńskiego

\title{
PRZESTĘPCZOŚĆ NIELETNICH W ŚWIETLE BADAŃ AKT SPRAW SĄDOWYCH A PROBLEM ODPOWIEDZIALNOŚCI RODZICÓW ZA SZKODY WYRZĄDZONE PRZEZ ICH DZIECI
}

\section{CEL, METODA, DOBÓR PRÓBY I ORGANIZACJA BADANIA}

Sprawy dotyczące odpowiedzialności rodziców za szkodę wyrządzoną przez ich dziecko są rozpatrywane w postępowaniu cywilnym w trybie procesowym. Roszczenie strony wnoszącej powództwo może wynikać z art. 427 bądź 415 k.c. Właściwość rzeczową sądu należy oceniać $\mathrm{w}$ tym przypadku stosownie do reguł określonych w art.16 oraz 17 pkt. 4), a więc w zależności od wartości przedmiotu sporu. O ile nie przekracza ona siedemdziesięciu pięciu tysięcy złotych, sprawy należą do właściwości sądu rejonowego, natomiast w przeciwnym przypadku - są rozpatrywane przez sądy okręgowe.

Przeprowadzenie badań aktowych w wydziałach cywilnych sądów rejonowych i okręgowych okazało się niemożliwe $\mathrm{z}$ następujących względów. Z przeprowadzonego wśród pracowników sądów i samych sędziów wywiadu wynikało, że omawiany rodzaj spraw sądowych występuje obecnie sporadycznie. Zgromadzenie odpowiedniej liczby akt sądowych do badań wymagałoby zatem uzyskania dostępu do archiwów wszystkich sądów w Polsce, co z oczywistych względów było niewykonalne. Ponadto sprawy o odszkodowanie z tytułu 
szkody wyrządzonej przez dziecko, w których pozwanymi są rodzice, nie są w sposób szczególny ujmowane w repertoriach sadowych. Mieszczą się w szerokiej kategorii spraw „o odszkodowanie”, co praktycznie uniemożliwia ich wyselekcjonowanie spośród całości akt sądowych.

Podstawowym celem planowanych badań aktowych nie było jednak poznanie przebiegu procesu o odszkodowanie w omawianym przypadku, ale analiza stanu faktycznego, w którym dochodzi do wyrządzenia szkody przez dziecko, w szczególności poznanie jego sytuacji rodzinnej, okoliczności w których dochodzi do wyrządzenia szkody, ewentualnego wpływu rodziców na jej wystapienie, uwarunkowań społecznych tego zdarzenia. Szczególnie istotne z punktu widzenia przedmiotu niniejszego opracowania było zweryfikowanie tezy o korelacji pomiędzy jakością procesu wychowawczego prowadzonego przez rodziców, a zachowaniem dziecka przejawiającym się popełnianiem czynów karalnych. Uzyskanie odpowiedzi w wymienionych kwestiach warunkuje sformułowanie zarówno wniosków de lege lata, jak i de lege ferenda.

Bardzo dobrym materiałem badawczym, pozwalającym uzyskać informacje w wymienionych wyżej kwestiach, okazały się być akta spraw sądowych, toczących się według przepisów ustawy o postępowaniu w sprawach nieletnich. Jak wiadomo, znajdują one między innymi zastosowanie w zakresie zapobiegania i zwalczania demoralizacji osób, które nie ukończyły 18 lat oraz w sprawach o czyny karalne, których dopuściły się osoby po ukończeniu 13 lat, a przed ukończeniem lat $17^{1}$. Zakres przedmiotowy ustawy o postępowaniu w sprawach nieletnich nie pokrywa się zatem z wszystkimi przypadkami odpowiedzialności rodziców za szkodę wyrządzoną przez ich dziecko. W szczególności, poza zakresem zainteresowania tej ustawy pozostają sytuacje, w których dochodzi do wyrządzenia szkody przez dziecko bardzo małe lub chore psychicznie i przez to nie ponoszące winy, ani nie przejawiające objawów demoraliza-

${ }^{1}$ Artykuł $1 \S 1$ pkt 1) i 2) ustawy o postępowaniu w sprawach nieletnich (Dz.U. z 1982 r. Nr 35, poz. 228 ze zm.). 
cji. Niemniej zarówno kodeks cywilny jak i ustawa o postępowaniu w sprawach nieletnich odnoszą się do przypadków, w których odpowiedzialność cywilna może zostać przypisana zarówno dziecku, jak i jego rodzicom. Takie właśnie sytuacje, w których czyn karalny obejmował jednocześnie wyrządzenie szkody zostały objęte badaniem aktowym.

Za objęciem badaniem spraw nieletnich zdecydowanie przemawiała społeczna skala zjawiska przestępczości nieletnich. Według danych Komendy Głównej Policji, opublikowanych na jej stronie internetowej, w 2007 roku nieletni powyżej 13 roku życia dopuścili się 72476 czynów karalnych ${ }^{2}$. Warto przy tym zwrócić uwagę na charakter najczęściej popełnianych przestępstw. Najliczniejszą ich grupę stanowią kradzieże z włamaniem (9 185) oraz kradzieże i wymuszenia rozbójnicze (7 511). Stosunkowo liczną grupę stanowią czyny, których konsekwencją był uszczerbek na zdrowiu (3 534) ${ }^{3}$. We wszystkich tych przypadkach można mówić o powstaniu szkody cywilnej i obowiązku jej naprawienia. Również w grupie nieletnich, którzy nie ukończyli 13 lat najczęściej występowały kradzieże (498 przypadków), kradzieże z włamaniem (358), czyny, których skutkiem był uszczerbek na zdrowiu (208), uszkodzenia rzeczy (255). W sumie, nieletni ci popełnili w 2007 roku 2319 czynów karalnych ${ }^{4}$.

Kolejnym argumentem na rzecz przeprowadzenia badań aktowych spraw nieletnich było zamieszczenie przez ustawodawcę $\mathrm{w}$ ustawie o postępowaniu w sprawach nieletnich przepisu art. $7 \S 1 \mathrm{pkt}$ 2), zgodnie z którym sąd rodzinny może zobowiązać rodziców lub opiekuna do naprawienia w całości lub w części szkody wyrządzonej przez nieletniego. Przepis tej treści świadczy o ścisłej zależności pomiędzy przypadkami rozstrzyganymi w trybie ustawy o postępowaniu w sprawach nieletnich, a sprawami cywilnymi, których przedmiotem jest szkoda wyrządzona przez dziecko.

\footnotetext{
${ }^{2} \mathrm{http}: / /$ www.policja.pl/portal/pol/4/306/Nieletni_przestepczosc.html ${ }^{3} \mathrm{http}: / /$ www.policja.pl/portal/pol/4/306/Nieletni_przestepczosc.html. ${ }^{4} \mathrm{http}: / /$ www.policja.pl/portal/pol/4/306/Nieletni_przestepczosc.html.
} 
Badanie aktowe zostało przeprowadzone przy pomocy kwestionariusza do badania akt sądowych Został on podzielony na sześć działów. Pierwszy z nich, zatytułowany „Informacje wstępne” służył zebraniu podstawowych informacji dotyczacych daty popełnienia czynu karalnego, czasu prowadzenia postępowania przez policję i daty prawomocnego orzeczenia sądu.

Dział II, zatytułowany „Informacje dotyczące małoletniego” i zawierający trzynaście pytań, służył zobrazowaniu sylwetki nieletniego poprzez uzyskanie informacji na temat jego wieku, rodzeństwa, realizacji obowiązku szkolnego i postępów w nauce, zachowania przed wyrządzeniem szkody i rodzaju ewentualnych trudności wychowawczych, ewentualnych czynników negatywnie wpływających na wychowanie małoletniego oraz popełniania przez niego czynów karalnych w przeszłości.

Dział III nosił tytuł „Informacje dotyczące rodziców nieletniego” i składał się również z trzynastu pytań. Motywem ich sformułowania było uzyskanie informacji dotyczących sytuacji rodzinnej nieletniego i charakteru środowiska, w którym był on wychowywany. Pytania dotyczyły wieku i wykształcenia rodziców, ich źródła utrzymania, wykonywanego zawodu, sytuacji finansowej rodziny. Szczególnie istotna grupa pytań służyła zobrazowaniu sposobu wykonywania władzy rodzicielskiej przez rodziców, w tym z kim dziecko zamieszkiwało w momencie wyrządzenia szkody, jaki był stan prawny i faktyczny w zakresie wykonywania władzy rodzicielskiej, czy rodzice pozostawali w związku małżeńskim oraz jakie były ewentualne przyczyny rozbicia rodziny.

Zawierający osiem pytań dział IV został zatytułowany „Informacje dotyczące wyrządzonej szkody". Jego celem było przybliżenie zdarzenia polegającego na wyrządzeniu szkody oraz jego konsekwencji, poprzez zbadanie takich kwestii jak rodzaj popełnionego czynu karalnego, wysokość wyrządzonej szkody, charakter ewentualnej szkody na osobie. Postawiono również pytania dotyczące tego, czy szkoda została naprawiona, w jaki sposób to nastapiło oraz kto tego dokonał i jakie były motywy naprawienia szkody. 
Dział V poświęcony został przebiegowi postępowania sądowego, składał się z trzech pytań i został zatytułowany „Informacje dotyczące postępowania sądowego". Pytania dotyczyły rodzaju przeprowadzonych dowodów w postępowaniu sądowym, rodzaju zastosowanych przez sąd środków przewidzianych przez ustawę o postępowaniu w sprawach nieletnich oraz tego, czy sąd skorzystał z przewidzianej w art. $7 \S 1$ pkt 2) wspomnianej ustawy możliwości zobowiązania rodziców do naprawienia szkody wyrządzonej przez nieletniego.

Ostatni dział (,VI Ocena stanu faktycznego wynikającego z akt, gdy chodzi o jego przyczyny") obejmował trzy pytania odwołujące się do oceny autora badań dotyczącej stanu faktycznego i wskazania osób ponoszących winę w związku z zaistniałym zdarzeniem oraz przyczyn, które do niego doprowadziły.

Dobór akt sądowych miał charakter losowy, a warunkiem ich zakwalifikowania do badania było popełnienie przez nieletniego czynu, który był równoznaczny z wyrządzeniem szkody oraz potwierdzenie tego faktu w postępowaniu sądowym. Nie były objęte badaniem te akta, z których wynikało, że nieletni, mimo toczącego się postępowania sądowego, zarzucanego pierwotnie czynu nie popełnił.

Analiza akt sądowych prowadzona była w sekretariatach sądów rodzinnych przez autora niniejszego opracowania przy wykorzystaniu opisanego wyżej kwestionariusza.

\section{PoDSTAWOWE INFORMACJE NA TEMAT BADANYCH SPRAW NIELETNICH}

Badanie objęło 200 spraw nieletnich. Prowadzone było w wydziałach rodzinnych i nieletnich sądów rejonowych przede wszystkim w Warszawie: 83 ankiety przeprowadzono w Wydziale XII Sądu Rejonowego dla m.st. Warszawy, $61 \mathrm{w}$ Wydziale XI, a 20 w Wydziale IX tego sądu. W Sądzie Rejonowym w Pruszkowie zostało przeprowadzonych 36 ankiet. Czyny będące przedmiotem badanych spraw zostały popełnione w latach 1999-2005. Poniższa tabela określa szczegółowo liczbę zbadanych z podziałem na lata, w których popełniono czyn będący przyczyną toczącego się postępowania. 
Tabela 1. Badane sprawy wedtug daty (roku) popetnienia czynu karalnego

\begin{tabular}{|c|c|c|}
\hline \multirow{2}{*}{$\begin{array}{c}\text { Rok, w którym zostat } \\
\text { popetniony czyn karalny }\end{array}$} & \multicolumn{2}{|c|}{ Badane sprawy } \\
\cline { 2 - 3 } 1998 & 1 & w odsetkach \\
1999 & 2 & 0,5 \\
2000 & 7 & 1 \\
2001 & 69 & 3,5 \\
2002 & 36 & 34,5 \\
2003 & 68 & 18 \\
2004 & 16 & 34 \\
2005 & 1 & 8 \\
\hline
\end{tabular}

Badanie pozwoliło również określić odstęp czasu, który upłynął od popełnienia czynu karalnego do wydania przez sąd prawomocnego wyroku.

Tabela 2. Czas od popetnienia czynu karalnego do wydania prawomocnego wyroku

\begin{tabular}{|l|c|c|}
\hline \multirow{2}{*}{$\begin{array}{l}\text { Czas od popetnienia czynu karalnego } \\
\text { do wydania prawomocnego wyroku }\end{array}$} & B liczbach bezwzględnych & wodsetkach \\
\cline { 2 - 3 } & 105 & 52,5 \\
do 6 miesięcy & 72 & 36 \\
powyżej 6 m-cy do 12 m-cy & 18 & 9 \\
powyżej 12 m-cy do 24 m-cy & 5 & 2,5 \\
powyżej 24 miesięcy & 200 & 100 \\
\hline Ogółem & & \\
\hline
\end{tabular}

Proporcje pomiędzy wyróżnionymi wyżej grupami spraw obrazuje poniższy wykres. 

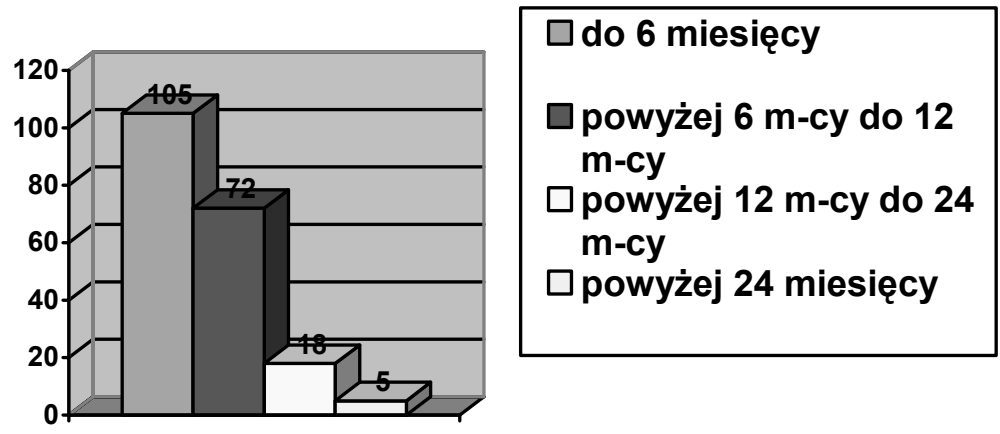

Wykres 1. Czas od popetnienia czynu karalnego do wydania prawomocnego wyroku

Z powyższego wykresu wynika, że zdecydowana większość postępowań, tj 177 (88,5\%) zostało zamkniętych w okresie jednego roku od popełnienia czynu karalnego. Przy tym największą, spośród wyróżnionych powyżej grup stanowi ta, w której postępowanie zamknięto w okresie 6-ciu miesięcy od popełnienia czynu karalnego (105 przypadków, co stanowi 52,5\% ogólnej liczby badanych spraw).

Szybkie rozpatrzenie spraw nieletnich jest obowiązkiem sądu i jest możliwe ze względu na ich specyfikę, w szczególności z uwagi na to, że wykrycie popelnionego czynu i ustalenie jego sprawców nie stanowi z reguły problemu. Postępowanie dowodowe przed sądem koncentruje się $\mathrm{z}$ reguły na ustaleniu sytuacji nieletniego $\mathrm{w}$ zakresie jego zdrowia psychicznego, uwarunkowań rodzinnych, dotychczasowego zachowania itp., natomiast sam fakt popełnienia określonego czynu pozostaje $\mathrm{z}$ reguły bezsporny. W sprawach nieletnich konieczność szybkiego ich rozpatrywania jest szczególnie istotna w kontekście ochrony dobra dziecka i dlatego wydłużenie postępowania sądowego ponad 6 miesięcy można oceniać krytycznie. W takim czasie rozpatrywano 95 spraw (47,5\%), a więc blisko połowę.

Osiemnaście spraw (9\%) zostało zakończonych w przedziale między 12 a 24 miesiącami, a zaledwie 5 (2,5\%) po dwóch latach.

Wśród badanych spraw nie było ani jednego przypadku przedłużenia postępowania sądowego przez odwołanie do sądu wyższej instancji. 


\section{INFORMACJE DOTYCZĄCE NIELETNICH WYRZĄZZAJĄCYCH SZKODĘ}

Zgodnie $\mathrm{z}$ art. $1 \S 1$ ustawy o postępowaniu w sprawach nieletnich, jej przepisy stosuje się m.in. w zakresie:

1) zapobiegania i zwalczania demoralizacji - w stosunku do osób, które nie ukończyły lat 18 ,

2) postępowania w sprawach o czyny karalne - w stosunku do osób, które dopuściły się takiego czynu po ukończeniu lat 13, ale nie ukończyły lat 17.

Artykuł 2 wymienionej ustawy stanowi, iż ,przewidziane w ustawie działania podejmuje się w wypadkach, gdy nieletni wykazuje przejawy demoralizacji lub dopuści się czynu karalnego".

Badaniem objęto nieletnich niezależnie od wieku. Jakkolwiek, zgodnie z przytoczonym wyżej unormowaniem postępowanie o czyny karalne określone w ustawie może się toczyć w stosunku do małoletnich, którzy ukończyli 13 lat i nie ukończyli lat 17, to jednak popełnienie tego rodzaju czynów przez młodsze dzieci stanowi najczęściej pierwszą z wymienionych podstaw do wszczęcia postępowania, bedąc przejawem demoralizacji w rozumieniu art. 4 ustawy $^{5}$. Tak więc postępowanie może zostać wszczęte w stosunku do nieletnich, którzy nie ukończyli 13 lat, a nawet w pewnych przypadkach w stosunku do tych, którzy ukończyli 17 lat, a nie ukończyli lat $18^{6}$.

Poniższa tabela dostarcza informacji na temat wieku nieletnich oraz ich płci. Wiek nieletnich został obliczony przy uwzględnieniu czasu popełnienia przez nich czynu karalnego.

${ }^{5}$ Jest nią „w szczególności naruszanie zasad współżycia społecznego, popełnienie czynu zabronionego, systematyczne uchylanie się od obowiązku szkolnego lub kształcenia zawodowego, używanie alkoholu lub innych środków w celu wprowadzenia się w stan odurzenia, uprawianie nierządu, włóczęgostwo, udział w grupach przestępczych"; Por. art. 4 ustawy o postępowaniu w sprawach nieletnich (tekst jedn. Dz.U. z 2002 r. Nr 11 poz. 109 ze zm.).

${ }^{6} \mathrm{~W}$ przypadku osób, które ukończyły 17 , a nie ukończyły 18 lat, chodzi o popełnienie wykroczenia, które nie jest czynem karalnym w rozumieniu ustawy o postępowaniu w sprawach nieletnich, a jest jednocześnie przejawem demoralizacji. Por. K. GromeK, Komentarz do ustawy o postępowaniu w sprawach nieletnich, Warszawa 2004, s. 78. 
Tabela 3. Nieletni wedtug wieku $w$ chwili popetnienia czynu karalnego oraz plci.

\begin{tabular}{|c|c|c|c|c|c|c|}
\hline \multirow{2}{*}{$\begin{array}{l}\text { Wiek nieletniego } \\
\text { (liczba ukończo- } \\
\text { nych lat życia) }\end{array}$} & chtopcy & $\begin{array}{l}\text { dziew- } \\
\text { czynki }\end{array}$ & ogótem & chtopcy & $\begin{array}{l}\text { dziew- } \\
\text { czynki }\end{array}$ & ogółem \\
\hline & \multicolumn{3}{|c|}{ w liczbach bezwzględnych } & \multicolumn{3}{|c|}{ wodsetkach } \\
\hline 9 & 1 & 0 & 1 & 0,5 & 0 & 0,5 \\
\hline 10 & 1 & 1 & 2 & 0,5 & 0,5 & 1 \\
\hline 11 & 2 & 1 & 3 & 1 & 0,5 & 1,5 \\
\hline 12 & 5 & 0 & 5 & 2,5 & 0 & 2,5 \\
\hline 13 & 19 & 2 & 21 & 9,5 & 1 & 10,5 \\
\hline 14 & 39 & 7 & 46 & 19,5 & 3,5 & 23 \\
\hline 15 & 52 & 12 & 64 & 26 & 6 & 32 \\
\hline 16 & 53 & 5 & 58 & 26,5 & 2,5 & 29 \\
\hline Ogótem & 172 & 28 & 200 & 86 & 14 & 100 \\
\hline
\end{tabular}

Jak wynika z powyższej tabeli, istnieje zdecydowana dysproporcja pomiędzy popełnianiem czynów karalnych przez chłopców i dziewczęta. Można to zilustrować następującym wykresem.

Wykres 2. Nieletni wedtug wieku w chwili popetnienia czynu karalnego oraz płci.

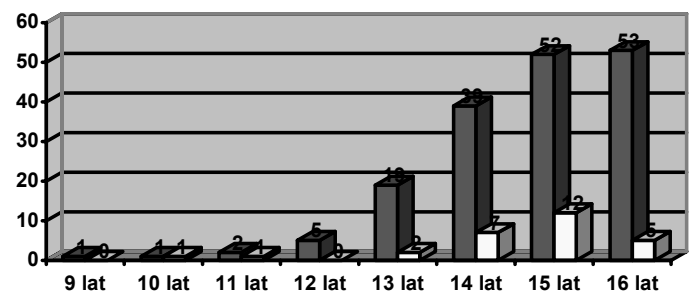

口Chłopcy

口Dziewczynki

Z wykresu nr 2 wynika, że wspomniana dysproporcja ujawnia się przede wszystkim w grupie dzieci starszych, pogłębiając się wraz z wiekiem. Wśród dzieci młodszych uzyskiwane liczby są zbliżone, a zdarzenia, które spowodowały wszczęcie postępowania w trybie ustawy o postępowaniu w sprawach nieletnich można określić jako sporadyczne.

W całym badaniu, obejmującym 200 spraw, nie odnotowano przypadku postępowania prowadzonego w odniesieniu do dziecka nie mającego ukończonych 9-ciu lat. Odnotowano jedną sprawę 9- 
letniego chłopca, jeden przypadek 10-letniego chłopca i jeden 10letniej dziewczynki, 2 przypadki 11-letnich chłopców i jedną sprawę 11-letniej dziewczynki, oraz 5 przypadków spraw sądowych dotyczących dwunastoletnich chłopców. Nie odnotowano przypadków popełnienia czynów karalnych przez dwunastoletnie dziewczynki, co nie jest zgodne $\mathrm{z}$ obserwowaną tendencją wzrostu przestępczości nieletnich wraz $\mathrm{z}$ wiekiem, ale może być tłumaczone niewielką próbą badawczą. W grupie dzieci, które nie ukończyły 13 roku życia badaniem objęto 9-ciu chłopców oraz 2 dziewczynki, natomiast $\mathrm{w}$ grupie dzieci mających ukończone 13 lat: 163 chłopców oraz 26 dziewcząt. W całym badaniu wystapiło 172 chłopców i 28 dziewcząt.

Wykres 3. Nieletni, którzy ukończyli badź nie ukończyli 13-tu lat
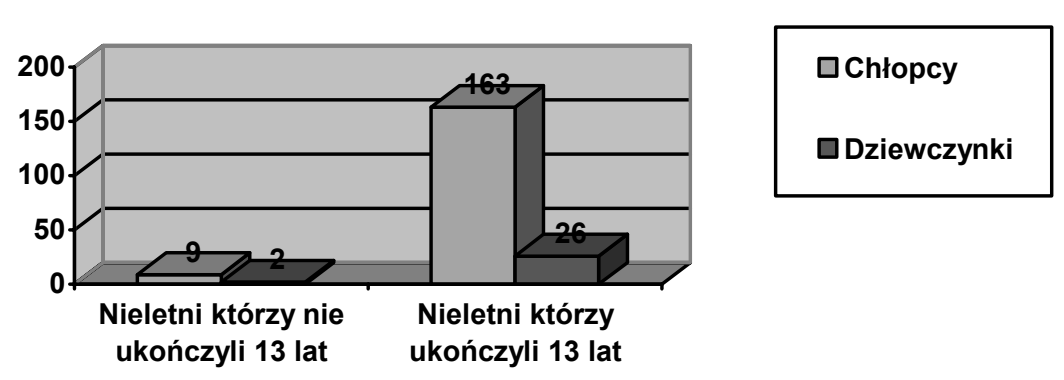

Jak wynika z powyższego wykresu, w porównaniu z liczbą 189 spraw nieletnich mających ukończone 13 lat, liczba spraw młodszych nieletnich, którzy nie ukończyli 13-tu lat (11 przypadków) może być określona jako znikoma.

Sprawy sądowe tego rodzaju, rozpatrywane w trybie ustawy o postępowaniu w sprawach nieletnich dotyczą ich demoralizacji. Oznacza to, że nie musiało dojść do popełnienia czynu karalnego, a podstawą wszczęcia postępowania było wystapienie samych przejawów demoralizacji (wagarowanie, używanie alkoholu itp.). W takich przypadkach akta spraw, jako bezużyteczne z punktu widzenia niniejszego opracowania nie były zakwalifikowane do badań aktowych. 
Jednakże całość zebranych danych wskazuje na wzrost przestępczości nieletnich wraz z ich wiekiem. Stwierdzenie to najlepiej obrazuje poniżej przedstawiony wykres:

Wykres 4. Badane sprawy nieletnich wedtug ich wieku oraz ptci

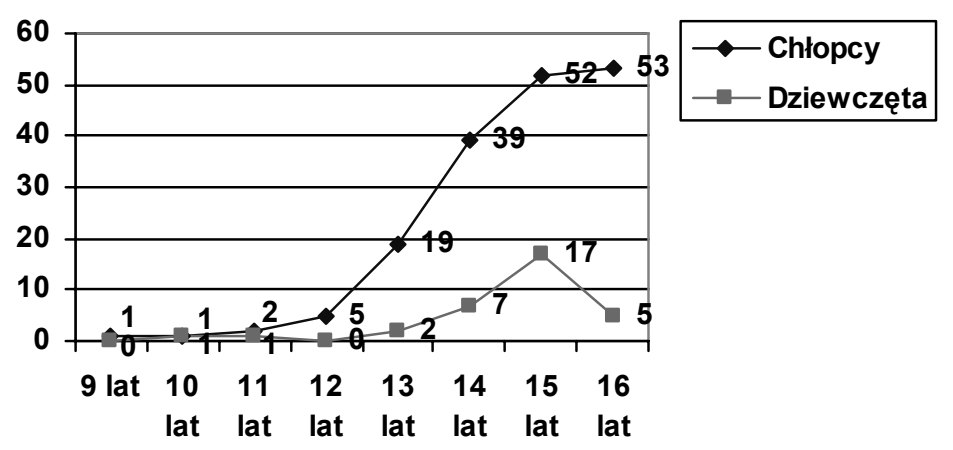

Analiza wyników badań w grupie nieletnich, którzy ukończyli 13 lat, wskazuje, iż wzrost popełnianych czynów karalnych ma charakter płynny i następuje wraz z wiekiem. Odnotowano 19 przypadków 13-letnich chłopców, a więc liczbę nie odbiegającą znacznie od liczby przypadków w grupie młodszych chłopców. W następnych latach liczba ta wzrasta do $39 \mathrm{w}$ 14-tym roku życia i osiaga poziom 52 i 53 przypadków odpowiednio w 15-tym i 16-tym roku życia. W grupie dziewcząt odstępstwem od opisywanej prawidłowości jest niewielka liczba spraw sądowych w grupie najstarszych - 16-letnich nieletnich (5 przypadków). Można to thumaczyć niewielką próbą badawczą w tej grupie, jak również wcześniejszym dojrzewaniem dziewcząt w porównaniu $\mathrm{z}$ chłopcami.

Opisywane prawidłowości posiadają istotne znaczenie dla głównego przedmiotu niniejszego opracowania. Analiza przepisów prawnych dotyczących odpowiedzialności cywilnej rodziców za szkodę wyrządzoną przez ich dziecko będzie przedmiotem dalszych części niniejszego opracowania. Niemniej już w tym miejscu należy zwrócić uwagę na to, iż główne unormowanie kodeksu cywilnego dotyczące tego problemu ma na względzie przede wszystkim odpowiedzialność 
rodziców za młodsze dzieci. Zgodnie bowiem z treścią art. 427 k.c. odpowiedzialność tą (na zasadach określonych w tym przepisie) można rodzicom przypisać wtedy, gdy ich dziecko nie ponosi winy z powodu wieku albo stanu psychicznego lub cielesnego. Jak wskazuja opisane dotychczas wyniki badań, w praktyce problem wyrządzania szkody przez dzieci występuje przeważnie w starszej grupie nieletnich, a więc takich, którym $\mathrm{z}$ reguły pewien stopień winy można przypisać. Funkcjonalność takiego rozwiązania legislacyjnego pozwoli ocenić dalsza analiza wyników badań.

Pytania zawarte w kwestionariuszu badań aktowych dostarczyły informacji na temat realizacji obowiązku szkolnego przez nieletnich. Ponieważ w pewnych przypadkach nieletni powtarzali klasy, sama informacja na temat ich wieku nie pozwoliłaby na ustalenie etapu edukacji, na którym się oni znajdowali. Ponadto celowe było również uzyskanie wiedzy dotyczącej ewentualnych trudności nieletnich w nauce. Kolejna tabela udziela odpowiedzi na pytanie do jakiej szkoły chodzili nieletni chwili wyrządzenia szkody.

Tabela 4. Nieletni wedtug szkoty do której uczęszczali w chwili popetnienia czynu karalnego

\begin{tabular}{|c|c|c|c|}
\hline \multirow{2}{*}{\multicolumn{2}{|c|}{$\begin{array}{l}\text { Rodzaj szkoły do której uczęszczał nieletni } \\
\text { w chwili popetnienia czynu karalnego }\end{array}$}} & \multicolumn{2}{|c|}{ Nieletni } \\
\hline & & $\begin{array}{c}\text { w liczbach } \\
\text { bezwzględnych }\end{array}$ & w odsetkach \\
\hline \multirow{2}{*}{\multicolumn{2}{|c|}{$\begin{array}{l}\text { szkoła podstawowa } \\
\text { gimnazjum }\end{array}$}} & 20 & 10 \\
\hline & & 117 & 58,5 \\
\hline \multirow{4}{*}{\multicolumn{2}{|c|}{\begin{tabular}{c|c} 
szkoła & $\begin{array}{c}\text { ogólnokształcace } \\
\text { ponadgimnazjalna } \\
\text { technikum } \\
\text { szkoła zawodowa }\end{array}$ \\
nieletni nie uczęszczat do żadnej szkoty w chwili \\
wyrzadzenia szkody
\end{tabular}}} & 22 & 11 \\
\hline & & 14 & 7 \\
\hline & & 16 & 8 \\
\hline & & 11 & 5,5 \\
\hline \multicolumn{2}{|c|}{ Ogótem } & 200 & 100 \\
\hline
\end{tabular}

Do gimnazjum uczęszczało 117 nieletnich, a więc ponad połowa badanej próby $(58,5 \%)$. Do szkół ponadgimnazjalnych uczęszczało w sumie 52 nieletnich $(26 \%)$. Najmniejsza grupa nieletnich $(20-10 \%)$ 
uczęszczała do szkoły podstawowej. W jedenastu przypadkach $(5,5 \%)$ nieletni nie uczęszczali do żadnej szkoły w chwili wyrządzenia szkody. W tej grupie pięciu nieletnich miało ukończone 16 lat, trzech -15 , dwóch -14 , a jeden -13 .

Badanie dotyczyło spraw prowadzonych w okresie wdrażania w życie reformy edukacji, dlatego ustalenie, czy nieletni powtarzał klasy przed popełnieniem czynu karalnego było dokonywane na podstawie konkretnej informacji na ten temat zawartej z reguły w aktach sprawy, a nie na podstawie porównania wieku nieletniego i klasy do której uczęszczał ${ }^{7}$.

Tabela nr 5 obrazuje realizację przez nieletnich obowiązku szkolnego z uwzględnieniem powtarzania przez nich klas oraz problemów w nauce. Informacje zawarte w aktach spraw sądowych nie pozwoliły na bardziej precyzyjny opis uzyskiwanych przez nieletnich wyników w nauce. W kategorii ,brak kłopotów” mieściły się przypadki, w których nieletni uzyskiwali pozytywne, niekoniecznie najlepsze oceny. Do kategorii ,złe wyniki w nauce” byli zaliczani ci nieletni, w których aktach znajdowały się wzmianki o różnego rodzaju trudnościach w nauce i złych ocenach powodujących stan zagrożenia, ale brak było stwierdzenia faktu powtarzania klas. Tak więc obie kategorie oznaczające trudności w nauce (,złe wyniki w nauce” oraz ,powtarzanie klas") były równoznaczne z bardzo poważnymi problemami nieletnich w szkole. W tym kontekście zwraca uwagę duża liczba spraw, w których tego rodzaju problemy zostały odnotowane. Przed popełnieniem czynu karalnego złe wyniki w nauce uzyskiwało 76, a klasy powtarzało 72 nieletnich. Oznacza to, że poważne problemy w szkole miało 148 nieletnich, a więc aż 74\% badanej próby. Brak kłopotów w nauce odnotowano w 49 przypadkach czyli w niespełna $1 / 4$ badanej próby $(24,5 \%)$. Jedynie wśród nieletnich uczęszczających do technikum przewagę uzyskała grupa młodzieży, która nie miała trudności w nauce (9 przypadków, 4 - złe wyniki, 1 - powtarzanie klas). W pozostałych przypadkach, tj. wśród nieletnich uczęszczających do szkoły podsta-

${ }^{7}$ Porównanie takie byłoby mylące również w przypadkach, gdy dziecko rozpoczęło realizację obowiązku szkolnego wcześniej bądź później. 
wowej, gimnazjum, zawodowej, a nawet liceum, większość stanowili ci, którym nauka sprawiała trudności. Warto zwrócić uwagę na fakt, że jedynie w grupie dzieci uczęszczających do szkoły podstawowej więcej z nich powtarzało klasy (12) niż odnotowywało jedynie złe wyniki w nauce (5).

Tabela 5. Nieletni wedtug szkoty do której uczęszczali w chwili popetnienia czynu karalnego oraz postępów w nauce przed popetnieniem tego czynu

\begin{tabular}{|c|c|c|c|c|c|c|c|}
\hline \multirow[b]{2}{*}{$\begin{array}{l}\text { Postęy } \\
\text { w nauce }\end{array}$} & \multicolumn{6}{|c|}{$\begin{array}{c}\text { Szkoła do której uczęszczał nieletni w chwili popetnienia } \\
\text { czynu karalnego }\end{array}$} & \multirow[b]{2}{*}{ razem } \\
\hline & 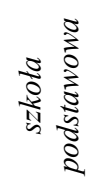 & 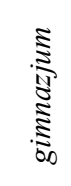 & 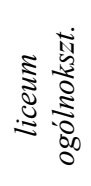 & 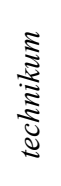 & 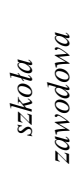 & 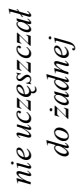 & \\
\hline \multicolumn{8}{|c|}{ w liczbach bezwzględnych } \\
\hline $\begin{array}{l}\text { Brak } \\
\text { kłopotów }\end{array}$ & 3 & 26 & 9 & 9 & 2 & 0 & 49 \\
\hline $\begin{array}{l}\text { Złe wyniki } \\
\text { w nauce }\end{array}$ & 5 & 47 & 8 & 4 & 9 & 3 & 76 \\
\hline $\begin{array}{l}\text { Powtarzanie } \\
\text { klas }\end{array}$ & 12 & 42 & 5 & 1 & 5 & 7 & 72 \\
\hline $\begin{array}{l}\text { Nie wynik. } \\
\text { z akt }\end{array}$ & 0 & 2 & 0 & 0 & 0 & 1 & 3 \\
\hline Razem & 20 & 117 & 22 & 14 & 16 & 11 & 200 \\
\hline \multicolumn{8}{|c|}{ w odsetkach } \\
\hline $\begin{array}{l}\text { Brak } \\
\text { kłopotów }\end{array}$ & 1,5 & 13 & 4,5 & 4,5 & 1 & 0 & 24,5 \\
\hline $\begin{array}{l}\text { Złe wyniki } \\
\text { w nauce }\end{array}$ & 2,5 & 23,5 & 4 & 2 & 4,5 & 1,5 & 38 \\
\hline $\begin{array}{l}\text { Powtarzanie } \\
\text { klas }\end{array}$ & 6 & 21 & 2,5 & 0,5 & 2,5 & 3,5 & 36 \\
\hline $\begin{array}{l}\text { Nie wynik. } \\
\text { z akt }\end{array}$ & 0 & 1 & 0 & 0 & 0 & 0,5 & 1,5 \\
\hline Razem & 10 & 58,5 & 11 & 7 & 8 & 5,5 & 100 \\
\hline
\end{tabular}


Jedynie w trzech przypadkach na podstawie akt sądowych nie można było ustalić, jakie wyniki w nauce uzyskiwał nieletni. Informacje na ten temat były standardowym elementem dowodów przeprowadzonych przez sąd, tj. wywiadów środowiskowych i opinii RODK, a wymierność wyników szkolnych nieletnich pozwalała zamieszczać tego rodzaju informacje w większości akt.

Oprócz danych przedstawionych w tabeli nr 5, w 27 sprawach na podstawie akt ustalono również występowanie szczególnych czynników mających wpływ na postępy nieletnich w nauce.

Tabela 6. Szczególne czynniki powiqzane z problemami w nauce nieletnich objętych badaniem

\begin{tabular}{|l|c|c|}
\hline \multirow{2}{*}{ Rodzaj problemu } & \multicolumn{2}{|c|}{ Nieletni } \\
\cline { 2 - 3 } & w liczbach bezwzgl. & wodsetkach \\
\hline Obniżenie sprawności intelektualnej & 8 & 4 \\
Dysleksja badź dysgrafia & 7 & 3,5 \\
Nauczanie indywidualne & 3 & 1,5 \\
Zakwalifikowany do nauczania & 6 & 3 \\
specjalnego & 1 & 0,5 \\
Fobia szkolna & 1 & 0,5 \\
Niedosłuch & 1 & 0,5 \\
Nerwica & 27 & 13,5 \\
Razem & 173 & 86,5 \\
Pozostałe sprawy w których & 200 & 100 \\
nie odnotowano tego typu czynników & & \\
\hline Ogółem & & \\
\hline
\end{tabular}

Jak wynika z powyższego zestawienia, jedynie w 27 przypadkach (13,5\% wszystkich badanych spraw, $18,24 \%$ w grupie 148 przypadków trudności nieletnich $\mathrm{w}$ nauce) $\mathrm{z}$ akt sądowych jednoznacznie wynikały okoliczności usprawiedliwiające brak postępów w nauce nieletnich. W pozostałych przypadkach takich sygnałów nie odnotowano.

W świetle powyższych ustaleń, jak również ze względu na znaczącą liczbę przypadków, w których odnotowano trudności nieletnich w nauce, właściwe wydaje się powiązanie tych sytuacji z procesem wychowawczym dzieci. Ich wystapienie może świadczyć o niewłaściwej realizacji funkcji wychowawczej rodziców, a w każdym przypadku 
powinno stanowić dla nich ostrzeżenie. Uzyskany materiał pozwala stwierdzić, że rodzice jeszcze przed popełnieniem przez ich dziecko czynu, który był podstawą wszczęcia postępowania sądowego w zdecydowanej większości przypadków otrzymywali takie ,sygnały ostrzegawcze".

$\mathrm{W}$ toku prowadzonych badań uzyskano również informacje, które bezpośrednio odnoszą się do problemów wychowawczych, występujących wśród nieletnich.

Tabela 7. Problemy wychowawcze nieletnich przed popetnieniem czynu karalnego

\begin{tabular}{|l|c|c|}
\hline Problemy wychowawcze przed & \multicolumn{2}{|c|}{ Nieletni } \\
\cline { 2 - 3 } popetnieniem czynu karalnego & w liczbach bezwzględnych & wodsetkach \\
\hline Brak & 54 & 27 \\
Wystapity & 124 & 62 \\
Nie wynikało z akt & 22 & 11 \\
\hline Ogółem & 200 & 100 \\
\hline
\end{tabular}

Zdecydowana większość badanych nieletnich, bo aż 124 (62\%), sprawiało poważne problemy wychowawcze jeszcze przed wyrządzeniem szkody. Liczbę tę należy przy tym uznać za minimum, co do którego istnieje pewność, ze względu na akta spraw, na podstawie których nie można było sformułować jednoznacznych wniosków co do zachowania nieletniego przed popełnieniem czynu karalnego. Jak można się domyślać również wśród tych przypadków w większości zaistniały problemy wychowawcze. W 54 przypadkach akta spraw pozwalały przyjąć, że nieletni nie sprawiali poważnych problemów wychowawczych przed popełnieniem czynu karalnego.

Tabela nr 8 zawiera bardziej szczegółowe dane na temat konkretnych przejawów demoralizacji nieletnich objętych badaniem, które wystapiły jeszcze przed wyrządzeniem szkody. 
Tabela 8. Nieletni wedlug wieku i problemów wychowawczych, które sprawiali przed popetnieniem czynu karalnego*

\begin{tabular}{|c|c|c|c|c|c|c|c|c|c|c|c|c|c|c|c|c|c|c|}
\hline \multirow{4}{*}{ 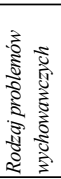 } & \multicolumn{18}{|c|}{ Nieletni } \\
\hline & \multicolumn{8}{|c|}{ mający ukończone lat } & \multirow{2}{*}{ 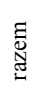 } & \multicolumn{8}{|c|}{ mający ukończone lat } & \multirow{2}{*}{$\begin{array}{l}\text { בี } \\
\text { స్․ }\end{array}$} \\
\hline & $a$ & 은 $+1+r+1+1$ & $=$ & $\simeq$ & $\underline{n}$ & $\Xi$ & 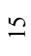 & $\stackrel{\varrho}{0}$ & & $a$ & 으 & $=$ & $\simeq$ & $\cong$ & \pm & 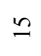 & 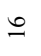 & \\
\hline & \multicolumn{9}{|c|}{ w liczbach bezwzglednych } & \multicolumn{9}{|c|}{ w odsetkach } \\
\hline 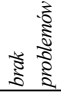 & - & 0 & o & - & r & 으 & 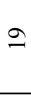 & $\stackrel{ }{-}$ & in & ? & 0 & 0 & $n$ & $m$ & in & $\tilde{\sigma}$ & $\infty$ & $\hat{\sim}$ \\
\hline 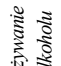 & 0 & 0 & 0 & 0 & $\nabla$ & $\infty$ & $\cong$ & 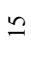 & F & 0 & 0 & 0 & 0 & $\sim$ & $\nabla$ & $n$ & $\stackrel{2}{\sim}$ & $\vec{\sim}$ \\
\hline 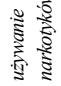 & 0 & 0 & 0 & 0 & $\mathrm{~N}$ & r & $\beth$ & \pm & $m$ & 0 & 0 & 0 & 0 & - & $\stackrel{n}{m}$ & 0 & r & $\stackrel{2}{=}$ \\
\hline 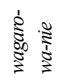 & 0 & - & $\mathrm{d}$ & - & $a$ & $\stackrel{\sim}{\sim}$ & $\stackrel{\infty}{\sim}$ & $\stackrel{\odot}{\sim}$ & 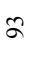 & 0 & "n & - & $\because$ & $\begin{array}{l}n \\
\sim\end{array}$ & 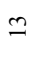 & \pm & $\cong$ & $\begin{array}{l}n \\
0 \\
f\end{array}$ \\
\hline 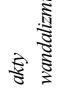 & 0 & 0 & 0 & 0 & $\mathrm{~N}$ & 0 & m & $\mathrm{N}$ & r & 0 & 0 & 0 & 0 & - & 0 & $\cong$ & - & $\stackrel{n}{m}$ \\
\hline 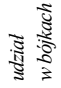 & 0 & 0 & - & N & in & $=$ & in & $\infty$ & लै & 0 & 0 & $n$ & - & $\tilde{\sim}$ & $\ddot{n}$ & $\tilde{n}$ & + & $\stackrel{\circ}{-}$ \\
\hline 苋 & 0 & 0 & 0 & 0 & $N$ & $N$ & $r$ & $N$ & $\underline{2}$ & 0 & 0 & 0 & 0 & - & - & $n$ & - & (n) \\
\hline 芯 & 0 & - & - & 0 & 0 & $m$ & $\nabla$ & ナ & 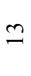 & 0 & $n$ & $n$ & 0 & 0 & $\because$ & $N$ & $\sim$ & n \\
\hline 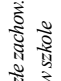 & 0 & 0 & - & 0 & - & 0 & m & 0 & in & 0 & 0 & $\because$ & 0 & 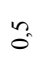 & 0 & $\because$ & 0 & in \\
\hline 恼 & 0 & 0 & 0 & - & - & 0 & $\sim$ & 0 & ナ & 0 & 0 & 0 & ? & 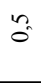 & 0 & - & 0 & $N$ \\
\hline 䛌 & 0 & 0 & 0 & - & 0 & in & $a$ & 0 & $\widetilde{N}$ & 0 & ñ & 0 & ? & 0 & $\hat{n}$ & $\stackrel{n}{\sim}$ & $n$ & $=$ \\
\hline
\end{tabular}

* jeden nieletni mógt sprawiać więcej niżjeden rodzaj problemów wychowawczych 
Rodzaje problemów wychowawczych zostały ujęte w kategorie, przy czym odczytując liczby zawarte $\mathrm{w}$ tabeli, należy mieć na względzie, że jednego nieletniego mogło dotyczyć kilka problemów wychowawczych. W zestawianiu znalazły się również takie kategorie, jak „złe zachowanie w szkole” oraz „nieposłuszeństwo wobec rodziców/ opiekunów". Ponieważ samo językowe brzmienie mogłoby sugerować zachodzenie ich zakresów pojęciowych na inne wskazane kategorie (np. wagarowanie), należy je rozumieć jako problemy o mniejszym natężeniu i różnych przejawach, innych jednak, niż pozostałe wyróżnione kategorie, na tyle jednak poważne, że zostały odnotowane w aktach sprawy sądowej.

Najczęściej występującym problemem wychowawczym było wagarowanie. Wystapiło ono w 93 przypadkach, co stanowi $46,5 \%$ badanej grupy, a więc prawie połowę. Problem ten odnotowano głównie wśród 14, 15 i 16-latków (odpowiednio: 26, 28 i 26 przypadków). Jako niepokojący należy podkreślić fakt częstego występowania wśród nieletnich problemu używania alkoholu i narkotyków. Odnotowano 42 przypadki (21\%) używania alkoholu oraz 35 przypadków $(17,5 \%)$ używania narkotyków. Wśród często występujących problemów wychowawczych należy jeszcze wskazać branie przez nieletnich udziału w bójkach (32 przypadki-16\%). Trzynastu nieletnich miało na swoim koncie ucieczki z domu i taka sama liczba - kradzieże. W siedmiu aktach spraw zawarta była informacja o wandalizmie nieletnich.

Podobnie jak w przypadku problemów szkolnych, jeśli chodzi o problemy wychowawcze, należy wskazać na znaczną ich liczbę w badanej grupie. Oznacza to, że we wszystkich tych przypadkach istniały wyraźne symptomy niewłaściwego przebiegu procesu wychowania dziecka, które powinny wywołać zdecydowane działania rodziców. 
Tabela 9. Kontakt nieletnich ze środowiskiem patologicznym przed popetnieniem czynu karalnego

\begin{tabular}{|l|c|c|}
\hline \multirow{2}{*}{$\begin{array}{l}\text { Kontakt nieletnich } \\
\text { ze środowiskiem } \\
\text { patologicznym przed } \\
\text { popetnieniem czynu }\end{array}$} & \multicolumn{2}{|c|}{ Nieletni } \\
\cline { 2 - 3 } & w liczbach bezwzględnych & wodsetkach \\
\hline Nie występowat & 103 & 51,5 \\
Występowat & 71 & 35,5 \\
Nie wynikało z akt & 26 & 13 \\
\hline Ogótem & 200 & 100 \\
\hline
\end{tabular}

Tabela nr 9 zawiera informacje na temat kontaktu nieletnich ze środowiskiem patologicznym. Należy przez nie rozumieć oddziaływanie o charakterze jednoznacznie demoralizującym ze strony rodziny bądź grupy koleżeńskiej. Chodzi tu o takie zjawiska jak alkoholizm, narkomania, konflikty z prawem, przemoc. Jakkolwiek w ponad połowie przypadków (103, co stanowi 51,5\%) zjawiska takiego na podstawie akt sądowych nie stwierdzono, to liczbę 71 (35,5\%) spraw, w których nieletni przed wyrządzeniem szkody stykali się ze środowiskiem patologicznym należy ocenić jako znaczącą. W przypadkach tych nie sposób nie dostrzegać związku pomiędzy wpływem najbliższego otoczenia na dziecko, a popełnianiem przez nie czynów karalnych. 
Tabela 10. Nieletni wedtug wieku i rodzaju kontaktów ze środowiskiem patologicznym przed popetnieniem czynu karalnego*

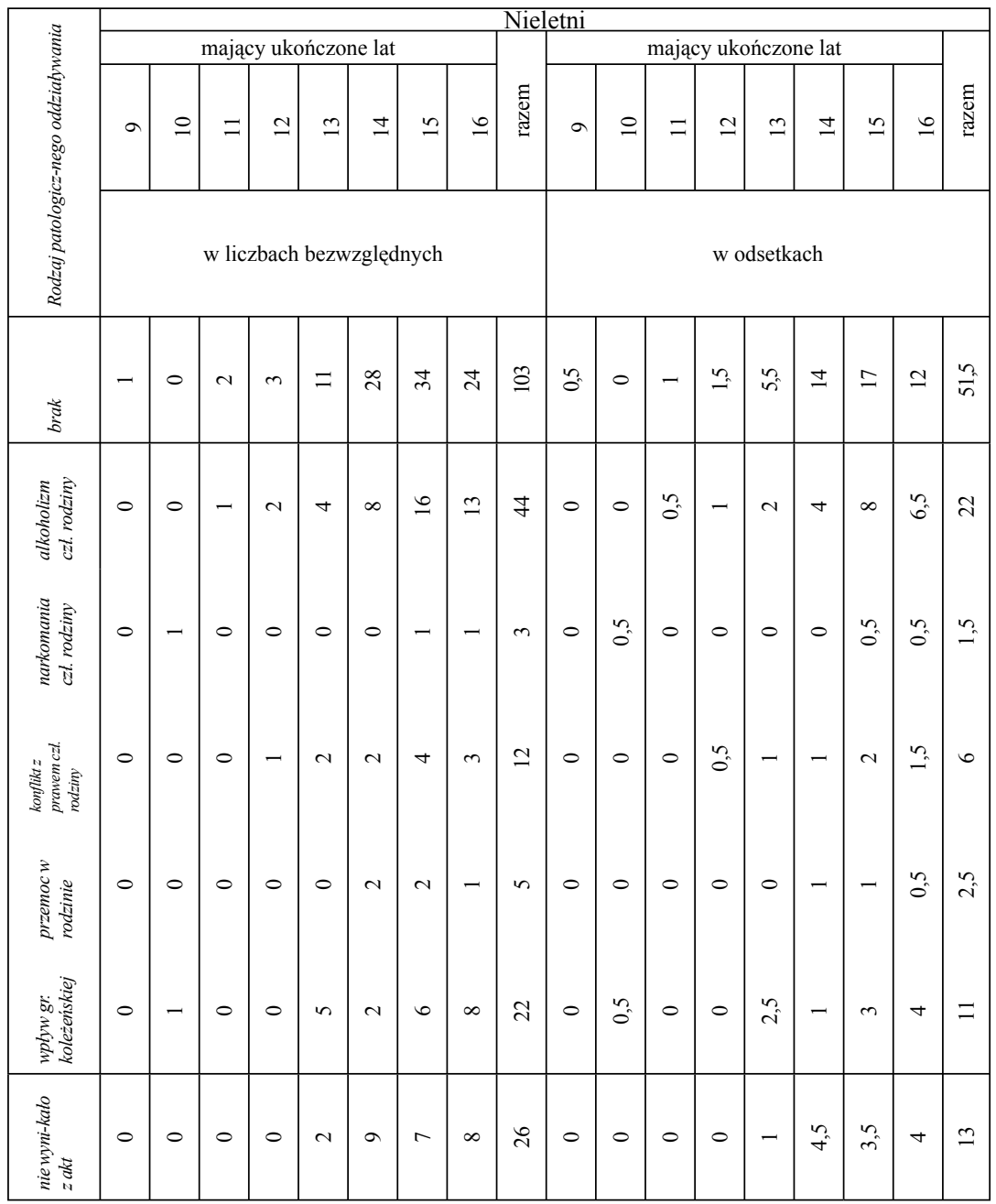
czynnikiem

* jeden nieletni mógt mieć kontakt $z$ więcej niż jednym 
W tabeli nr 10 przedstawione zostały dane dotyczące rodzaju patologicznego wpływu na nieletnich. Wynika z nich, że zdecydowanie najczęściej w badanych sprawach występował problem alkoholizmu jednego z członków najbliższej rodziny. Zjawisko to odnotowano aż w 44 sprawach (22\%). W 22 przypadkach (11\%) z akt sądowych wynikało, że źródłem demoralizującego wpływu na nieletniego była grupa koleżeńska ${ }^{8}$. W badaniu wystąpiły również sprawy, w których członkowie najbliższej rodziny nieletniego popadli w konflikt z prawem (12 przypadków). W pięciu aktach spraw znalazły się informacje o stosowaniu przemocy w rodzinie nieletniego. Należy mieć jednak na względzie, że fakt ten mógł być odnotowany przede wszystkim w przypadkach, w których z tego powodu zostały już podjęte kroki prawne i przez to stosowanie przemocy zostało ujawnione. Najrzadszym czynnikiem oddziałującym patologicznie na nieletnich była narkomania jednego z członków najbliższej rodziny ( 3 badane sprawy).

Tabela 11. Nieletni, którzy już wcześniej byli objęci postępowaniem za popetnione czyny karalne

\begin{tabular}{|l|c|c|}
\hline \multirow{2}{*}{$\begin{array}{l}\text { Popetnienie przez } \\
\text { nieletniego czynu karalnego } \\
\text { w przeszłości }\end{array}$} & \multicolumn{2}{|c|}{ Nieletni } \\
\cline { 2 - 3 } Nie wystapiło & 146 & w odsetkach \\
Wystapiło & 54 & 73 \\
\hline Ogótem & 200 & 100 \\
\hline
\end{tabular}

Jak wynika z powyższego zestawienia $\mathrm{w}$ ponad $1 / 4$ badanych spraw (54 przypadki $-27 \%$ ) istniały informacje na temat wcześniejszego konfliktu z prawem nieletnich, który był powodem wszczęcia postępowania w trybie ustawy o postępowaniu w sprawach nieletnich. Liczbę 54 takich spraw należy ocenić jako bardzo wysoką, zważywszy na fakt, że badaną grupę stanowiły osoby nieletnie. Stawia to pod znakiem zapytania skuteczność stosowanych środków przewidzianych w ustawie o postępowaniu w sprawach nieletnich, jak również sku-

${ }^{8} \mathrm{~W}$ tym przypadku w jednej kategorii mieszczą się różnego rodzaju patologie występujące w grupie koleżeńskiej, takie jak alkoholizm, narkomania, konflikty z prawem. 
teczność resocjalizacji nieletniego. Szczególną uwage powinno zwrócić w tym przypadku właściwe wykonywanie swoich funkcji przez rodziców nieletniego.

Tabela 12. Rodzaj popetnionego czynu, który byt przyczyna wszczęcia postepowania sadowego wobec nieletnich $w$ przeszłości*

\begin{tabular}{|l|c|c|}
\hline \multirow{2}{*}{\multicolumn{1}{|c|}{ Rodzaj zdarzenia }} & \multicolumn{2}{|c|}{ Nieletni } \\
\cline { 2 - 3 } & $\begin{array}{c}\text { wliczbach } \\
\text { bezwzględnych }\end{array}$ & wodsetkach \\
\hline Kradzież & 16 & 8 \\
Kradzież z włamaniem & 1 & 0,5 \\
Zniszczenie rzeczy & 6 & 3 \\
Rozbój & 2 & 1 \\
Pobicie & 8 & 4 \\
Demoralizacja/alkoholizm/narkomania & 3 & 1,5 \\
Rodzaj zdarzenia nie wynikat z akt & 22 & 11 \\
\hline
\end{tabular}

* jeden nieletni mógt popetnić więcej niż jeden czyn

Tabela nr 12 obejmuje grupę 54 spraw, w których nieletni byli już wcześniej objęci postępowaniem w związku z popełnieniem czynu karalnego. $Z$ tabeli tej wynika, że najczęstszą przyczyną toczących się wobec nieletnich postępowań jeszcze przed wszczęciem spraw objętych omawianym badaniem były kradzieże. W ośmiu przypadkach tą przyczyną było pobicie, a w sześciu - zniszczenie rzeczy. W 22 aktach spraw znalazły się informacje o prowadzeniu postępowania sądowego w sprawie nieletnich, ale brak było bliższych danych na temat rodzaju popełnionego czynu.

Bardziej istotne wydają się być informacje na temat rodzaju zastosowanych wobec nieletnich środków, przewidzianych w ustawie o postępowaniu w sprawach nieletnich. Dane te zawarte są w kolejnej tabeli (nr 13). Również ta tabela obejmuje grupę 54 spraw, w których nieletni byli już wcześniej objęci postępowaniem w związku z popełnieniem czynu karalnego. 
Tabela 13. Rodzaj środków (przewidzianych w ustawie o postępowaniu $w$ sprawach nieletnich) zastosowanych wobec nieletnich przed popetnieniem czynu, w badanych sprawach*

\begin{tabular}{|l|c|c|}
\hline \multirow{2}{*}{ Rodzaj środka } & \multicolumn{2}{|c|}{ Nieletni } \\
\cline { 2 - 3 } & $\begin{array}{c}\text { w liczbach } \\
\text { bezwzględnych }\end{array}$ & wodsetkach \\
\hline Upomnienie & 5 & 2,5 \\
Nadzór odpowiedzialny rodziców & 9 & 4,5 \\
Nadzór kuratora & 26 & 13 \\
Umieszczenie w placówce & 16 & 8 \\
opiekuńczo-wych. & 2 & 1 \\
Umieszczenie w placówce leczenia & 2 & 1 \\
uzależnieńn & 3 & 1,5 \\
Umieszczenie w zaktadzie & & \\
poprawczym & & \\
Rodzaj środka nie wynikat z akt & & \\
\hline
\end{tabular}

* w stosunku do jednego nieletniego mogło być orzeczonych więcej niż jeden środek

Wymienione w powyższej tabeli środki - ze względu na kolejny konflikt nieletnich z prawem - okazały się nieskuteczne. Ze względu na brak możliwości porównania tych danych z liczbą nieletnich, którzy nie popadli w ponowny konflikt z prawem, w tym miejscu należy ograniczyć się jedynie do zwrócenie uwagi na częste stosowanie przez sądy środka w postaci nadzoru kuratora. Rozwiązanie to wystapiło w 26 przypadkach (13\% badanej grupy). Nadzór kuratora jest jednym z najczęściej stosowanych w praktyce przez sądy środków wychowawczych ${ }^{9}$ co znajduje potwierdzenie w przytoczonych liczbach. Jako instrument pozwalający utrzymać nieletniego w jego środowisku rodzinnym jest stosowany wtedy, gdy sami rodzice nie gwarantują należytego przebiegu procesu wychowawczego ${ }^{10}$. Najczęściej więc można im w tych przypadkach przypisać winę za zaburzenie tego procesu.

${ }^{9}$ Por. K. GromeK, op. cit., s. 117.

${ }^{10}$ Por. K. Gromek, op. cit., s. 117 . W innym przypadku wystarczające byłoby orzeczenie środka w postaci nadzoru odpowiedzialnego rodziców. 


\section{NAJBLIŻSZA RODZINA NIELETNICH OBJĘTYCH BADANIEM}

Jak już wspomniano wcześniej, głównym celem przeprowadzonego badania aktowego było pozyskanie informacji dotyczących najbliższej rodziny nieletnich. Tabela $\mathrm{nr} 14$ zawiera informacje na temat wieku i wykształcenia ich rodziców.

Tabela 14. Rodzice nieletnich wedtug wieku $i$ wyksztatcenia w chwili popetnienia czynu karalnego

\begin{tabular}{|c|c|c|c|c|c|c|c|c|c|c|c|c|}
\hline \multirow[b]{3}{*}{$\begin{array}{l}W \text { i e } \\
\text { rodzica } \\
\text { (ukończ. } \\
\text { lata) }\end{array}$} & \multicolumn{12}{|c|}{ Wyksztatcenie rodzica } \\
\hline & \multicolumn{6}{|c|}{ ojca } & \multicolumn{6}{|c|}{ matki } \\
\hline & \begin{tabular}{l}
$\stackrel{N}{N}$ \\
$\stackrel{N}{N}$ \\
\multirow{2}{*}{}
\end{tabular} & 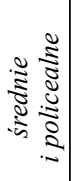 & 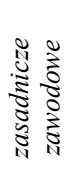 & 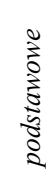 & 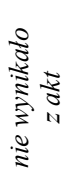 & $\frac{5}{8}$ & $\begin{array}{l}N \\
N \\
N \\
\text { N }\end{array}$ & 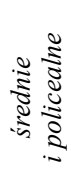 & 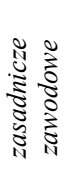 & 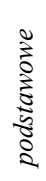 & 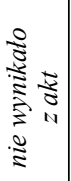 & 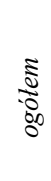 \\
\hline \multicolumn{13}{|c|}{ w liczbach bezwzględnych } \\
\hline nie żyje & 0 & 0 & 1 & 1 & 21 & 23 & 0 & 0 & 0 & 1 & 2 & 3 \\
\hline $30-39$ & 1 & 13 & 9 & 6 & 4 & 33 & 4 & 28 & 24 & 13 & 7 & 76 \\
\hline $40-49$ & 4 & 22 & 42 & 8 & 11 & 87 & 8 & 34 & 24 & 15 & 9 & 90 \\
\hline $50-59$ & 1 & 4 & 5 & 6 & 3 & 19 & 2 & 1 & 4 & 3 & 4 & 14 \\
\hline $60-69$ & 0 & 0 & 0 & 0 & 2 & 2 & 0 & 0 & 0 & 0 & 0 & 0 \\
\hline $70-79$ & 1 & 1 & 0 & 0 & 0 & 2 & 0 & 0 & 0 & 0 & 0 & 0 \\
\hline n.w.a. ${ }^{*}$ & 1 & 1 & 2 & 0 & 30 & 34 & 0 & 2 & 0 & 0 & 15 & 17 \\
\hline ogótem & 8 & 41 & 59 & 21 & 71 & 200 & 14 & 65 & 52 & 32 & 37 & 200 \\
\hline \multicolumn{13}{|c|}{ w odsetkach } \\
\hline nie żyje & 0 & 0 & 0,5 & 0,5 & 10,5 & 11,5 & 0 & 0 & 0 & 0,5 & 1 & 1,5 \\
\hline $30-39$ & 0,5 & 6,5 & 4,5 & 3 & 2 & 16,5 & 2 & 14 & 12 & 6,5 & 3,5 & 38 \\
\hline $40-49$ & 2 & 11 & 21 & 4 & 5,5 & 43,5 & 4 & 17 & 12 & 7,5 & 4,5 & 45 \\
\hline $50-59$ & 0,5 & 2 & 2,5 & 3 & 1,5 & 9,5 & 1 & 0,5 & 2 & 1,5 & 2 & 7 \\
\hline $60-69$ & 0 & 0 & 0 & 0 & 1 & 1 & 0 & 0 & 0 & 0 & 0 & 0 \\
\hline $70-79$ & 0,5 & 0,5 & 0 & 0 & 0 & 1 & 0 & 0 & 0 & 0 & 0 & 0 \\
\hline n.w.a. ${ }^{*}$ & 0,5 & 0,5 & 1 & 0 & 15 & 17 & 0 & 1 & 0 & 0 & 7,5 & 8,5 \\
\hline ogótem & 4 & 20,5 & 29,5 & 10,5 & 35,5 & 100 & 7 & 32,5 & 26 & 16 & 18,5 & 100 \\
\hline
\end{tabular}

* nie wynikało z akt

W badaniu nie odnotowano rodziców nie mających ukończonych 30tu lat. Najliczniejszą grupę stanowili rodzice między 40 a 49 rokiem życia 
(87 ojców i 90 matek). W przedziale między 30-tym, a 39-tym ukończonym rokiem życia wystapiło 33 ojców i 76 matek. W aktach spraw nie znalazły się informacje na temat matek między 60-tym, a 79-tym rokiem życia, natomiast odnotowano 4 takie przypadki wśród ojców.

Pod względem wykształcenia najliczniejszą grupę wśród mężczyzn stanowili ci z nich, którzy posiadali wykształcenie zasadnicze zawodowe (59 przypadków, co stanowiło $29,5 \%$ badanych spraw), natomiast wśród kobiet - wykształcenie średnie i policealne (65 przypadków $32,5 \%$ ). Najrzadziej w badaniu występowało wykształcenie wyższe - ustalono jedynie 8 (4\%) takich przypadków wśród ojców i 14 (7\%) wśród matek.

Uzyskane wyniki należy porównać z danymi uzyskanymi w ramach narodowego spisu powszechnego.

Tabela 15. Ludność miast wedtug wyksztatcenia, wieku i ptci w 2002 roku ${ }^{11}$

\begin{tabular}{|c|c|c|c|c|c|c|c|}
\hline \multirow{2}{*}{ Wiek } & Pó́tem & wyżze & $\begin{array}{c}\text { sirednie } \\
\text { ipolicealne }\end{array}$ & $\begin{array}{c}\text { zasadnicze } \\
\text { zawodowe }\end{array}$ & podstawowe & $\begin{array}{c}\text { podstawowe } \\
\text { nieukończ. }\end{array}$ & nie ustalono \\
\cline { 2 - 8 } & & & mężczyźni \\
\hline $35-39$ & 726507 & 116794 & 262572 & 267671 & 49972 & 2310 & 27188 \\
$40-44$ & 881705 & 125285 & 320724 & 335548 & 65594 & 2789 & 31765 \\
\hline \multicolumn{8}{|c|}{ kobiety } \\
\hline $35-39$ & 754761 & 154537 & 353680 & 168950 & 51372 & 1912 & 24310 \\
$40-44$ & 959216 & 159079 & 476935 & 214336 & 79145 & 2420 & 27301 \\
\hline
\end{tabular}

Z porównania przedstawionych powyżej danych wynika, że uzyskane w badaniu wyniki nie odbiegają znacząco pod względem wzajemnych proporcji liczb od danych narodowego spisu powszechnego. $\mathrm{W}$ badaniu aktowym uwagę zwraca jednak mniejszy odsetek rodziców z wykształceniem wyższym, jak również nieznacznie większy odsetek matek $\mathrm{z}$ wykształceniem zasadniczym zawodowym. I tak,

${ }^{11}$ Szczegółowe dane na temat struktury ludności, w tym poziomu wykształcenia zostały opublikowane na stronie internetowej Głównego Urzędu Statystycznego pod adresem internetowym: http://www.stat.gov.pl/gus/45_756_PLK_HTML.htm Tabela została opracowana na podstawie zamieszczonych tam danych. 
w badanych aktach sądowych rodzice w wieku 40-49 lat z wykształceniem wyższym stanowili 4,5\% (ojcowie) i 8,8\% (matki). W całej grupie liczby te były zbliżone i - jak już wspomniano - wynosiły 4\% (ojcowie) i 7\% (matki). Natomiast gdy chodzi o dane narodowego spisu powszechnego, w grupie osób w wieku 40-44 lat z wyższym wykształceniem mężczyźni stanowili ok. 14,2\% (125 285 przypadków na 881705 ), a kobiety ok. 16,5\% (159 079 przypadków na 959 216).

Mimo to wydaje się, iż przeprowadzone badanie nie dało jednoznacznych podstaw do stwierdzenia związku między poziomem wykształcenia rodziców, a zachowaniem ich dzieci.

Należy zaznaczyć, że w dużej liczbie przypadków (30, co stanowiło $15 \%$ badanej grupy), w ramach badania akt sądowych nie udało się ustalić informacji na temat wieku i wykształcenia ojców. Utrudnia to porównanie $\mathrm{z}$ danymi ogólnopolskimi. Było to spowodowane m.in. takimi czynnikami jak: śmierć ojca, brak ustalonego ojcostwa, brak zainteresowania ojca dzieckiem i związany z tym brak udziału ojca w sprawie sądowej dziecka. Z tabeli nr 14 wynika, że aż w 23 sprawach, tj. w 11,5\% badanej próby, ojcowie zmarli przed popełnieniem przez nieletnich czynu karalnego. Pozostałe czynniki zostaną omówione w dalszej części niniejszego opracowania.

Na podstawie akt sądowych zebrano również informacje na temat rodzeństwa nieletnich. Zostały one przedstawione w tabeli nr 16.

Najliczniejszą grupę stanowiły rodziny, w których nieletni miał jednego brata bądź siostrę. Odnotowano 57 takich przypadków, co stanowiło $28,5 \%$ wszystkich zbadanych akt. Druga co do wielkości grupa, w której nieletni był jedynakiem, liczyła 42 przypadki (21\%), natomiast największa liczba rodzeństwa (pięcioro) wystąpiła w 2 przypadkach (1\% spraw). 
Tabela 16. Rodzeństwo nieletnich wedlug liczby i starszeństwa

\begin{tabular}{|c|c|c|c|c|c|}
\hline \multirow{2}{*}{$\begin{array}{c}\text { Liczba } \\
\text { rodzeństwa }\end{array}$} & \multicolumn{5}{|c|}{ Rodzeństwo nieletnich } \\
\hline & starsze & młodsze & $\begin{array}{l}\text { starsze } \\
\text { i mlodsze }\end{array}$ & $\begin{array}{c}\text { starszeństwo } \\
\text { nie wynikato z akt }\end{array}$ & ogótem \\
\hline \multicolumn{6}{|c|}{ w liczbach bezwzględnych } \\
\hline 1 & 57 & 32 & nie dotyczy & 4 & 93 \\
\hline 2 & 18 & 11 & 10 & 3 & 42 \\
\hline 3 & 4 & 1 & 6 & 0 & 11 \\
\hline 4 & 0 & 2 & 3 & 0 & 5 \\
\hline 5 & 0 & 0 & 2 & 0 & 2 \\
\hline Ogółem & 79 & 46 & 21 & 7 & 153 \\
\hline $\begin{array}{l}\text { Brak } \\
\text { rodzeństwa }\end{array}$ & \multicolumn{4}{|c|}{ nie dotyczy } & 42 \\
\hline $\begin{array}{l}\text { Nie wynik. } \\
\text { z akt }\end{array}$ & \multicolumn{4}{|c|}{ nie dotyczy } & 5 \\
\hline \multicolumn{6}{|l|}{ w odsetkach } \\
\hline 1 & 28,5 & 16 & nie dotyczy & 2 & 46,5 \\
\hline 2 & 9 & 5,5 & 5 & 1,5 & 21 \\
\hline 3 & 2 & 0,5 & 3 & 0 & 5,5 \\
\hline 4 & 0 & 1 & 1,5 & 0 & 2,5 \\
\hline 5 & 0 & 0 & 1 & 0 & 1 \\
\hline Ogótem & 39,5 & 23 & 10,5 & 3,5 & 76,5 \\
\hline $\begin{array}{l}\text { Brak } \\
\text { rodzeństwa }\end{array}$ & \multicolumn{4}{|c|}{ nie dotyczy } & 21 \\
\hline $\begin{array}{l}\text { Nie wynik. } \\
\text { z akt }\end{array}$ & \multicolumn{4}{|c|}{ nie dotyczy } & 2,5 \\
\hline
\end{tabular}

Akta sądowe dostarczyły również informacji na temat starszeństwa dzieci wychowujących się w rodzinach objętych badaniem. Okazało się, że najczęściej nieletni sprawca czynu karalnego był najmłodszym z rodzeństwa. Odnotowano 79 takich przypadków, co stanowi $39,5 \%$ badanych akt. W 46 sprawach (23\%) nieletni był najstarszym z rodzeństwa, a w $21(10,5 \%)$ posiadał zarówno starsze jak i młodsze rodzeństwo. 
Tabela 17. Źródto utrzymania rodziców w chwili popetnienia czynu karalnego (wyrzadzenia szkody) przez ich dziecko

\begin{tabular}{|c|c|c|c|c|}
\hline \multirow{3}{*}{ Źródto utrzymania } & \multicolumn{4}{|c|}{ Rodzice nieletniego } \\
\hline & ojcowie & matki & ojcowie & matki \\
\hline & \multicolumn{2}{|c|}{ w liczbach bezwzględnych } & \multicolumn{2}{|c|}{ w odsetkach } \\
\hline Praca & 91 & 129 & 45,5 & 64,5 \\
\hline $\begin{array}{l}\text { Ni e z a robko we } \\
\text { (emerytura, renta, } \\
\text { zasilek) }\end{array}$ & 20 & 30 & 10 & 15 \\
\hline Na utrzymaniu matżonka & & & & \\
\hline lub innego członka & 21 & 31 & 10,5 & 15,5 \\
\hline rodziny & & & & \\
\hline Rodzic nie żyje & 23 & 3 & 11,5 & 1,5 \\
\hline Nie wynikało $z$ akt & 45 & 7 & 22,5 & 3,5 \\
\hline Ogółem & 200 & 200 & 100 & 100 \\
\hline
\end{tabular}

Z tabeli nr 17 wynika, że najliczniejszą grupę stanowili rodzice, którzy posiadali źródło utrzymania w postaci pracy, przy czym największą grupę stanowily tu matki $(129-64,5 \%)$, Pracujących ojców było $91(45,5 \%)$. Dysproporcja ta wynikała z opisywanej już niemożności uzyskania w dużej liczbie spraw informacji na temat ojców (tutaj 45) ze względu na brak zainteresowania ojca dzieckiem i brak jego udziału w sprawie sądowej. Niezarobkowe źródło utrzymania posiadało 20 ojców i 30 matek, natomiast na utrzymaniu małżonka bądź innego członka rodziny pozostawało 21 ojców i 31 matek. Prezentowane wyniki nie pozwalają na wyróżnienie istotnych korelacji w zakresie źródeł utrzymania gospodarstw domowych (ewentualnie bezrobocia) i wyrządzania szkody przez nieletnich. Dopełnieniem tych informacji są dane na temat poziomu zamożności (sytuacji majątkowej) rodzin, w których wychowywali się nieletni. Akta sądowe nie pozwoliły na bardzo precyzyjne określenie tej sytuacji poprzez wskazanie w każdym przypadku na wysokość zarobków rodziców nieletniego. Dlatego na podstawie całokształtu materiału dowodowego dokonano klasyfikacji sytuacji majątkowej gospodarstw domowych w czterostopniowej 
skali. Sytuacja „bardzo trudna” oznaczała krytyczny stan majątkowy rodziny o takich przejawach jak niezaspokojone potrzeby mieszkaniowe, konieczność korzystania z pomocy socjalnej, zaległości w opłatach, patologie w rodzinie i.t.p. Sytuacja „trudna” oznaczała problemy rodziny o mniejszym natężeniu, ale stanowiące zagrożenie dla jej stabilnego funkcjonowania, takie jak np. bezrobocie jednego z rodziców, korzystanie z pomocy dalszej rodziny, problemy z uzyskaniem alimentów. „Dobra” sytuacja oznaczała zaspokojenie niezbędnych potrzeb rodziny, natomiast „bardzo dobra” - wysoki stopień zamożności.

Tabela 18. Sytuacja majątkowa rodziny $w$ której nieletni wychowywat się w chwili popetnienia czynu karalnego (wyrzqdzenia szkody)

\begin{tabular}{|l|c|c|}
\hline Sytuacja finansowa & w liczbach bezwzględnych & wodsetkach \\
\hline Bardzo trudna & 32 & 16 \\
Trudna & 78 & 39 \\
Dobra & 69 & 34,5 \\
Bardzo dobra & 17 & 8,5 \\
Nie wynikało z akt lub nie dotyczy & 4 & 2 \\
\hline Ogótem & 200 & 100 \\
\hline
\end{tabular}

Zaprezentowane w tabeli nr 18 wyniki są bardziej wymowne i wskazują, iż w większości zbadanych przypadków (110, tj. 55\%) wystąpiły poważne (78) lub bardzo poważne (32) trudności natury ekonomicznej. Jedynie w 17 sprawach poziom zamożności rodziny można było określić jako wysoki. 
Tabela 19. Rodzice nieletnich wedtug pozostawania $w$ zwiqzku matżeńskim oraz zamieszkiwania $z$ dzieckiem $w$ chwili wyrzqdzenia przez nie szkody

\begin{tabular}{|c|c|c|c|c|c|}
\hline \multirow[t]{2}{*}{ Rodzice nieletniego } & \multicolumn{5}{|c|}{$\begin{array}{c}\text { Rodzice, którzy zamieszkiwali z nieletnim w chwili } \\
\text { wyrzqdzenia szkody }\end{array}$} \\
\hline & oboje & $\begin{array}{l}\text { tylko } \\
\text { ojciec }\end{array}$ & $\begin{array}{l}\text { tylko } \\
\text { matka }\end{array}$ & żadne & ogółem \\
\hline \multicolumn{6}{|c|}{ w liczbach bezwzględnych } \\
\hline Byli matżeństwem & 96 & 4 & 15 & 4 & 119 \\
\hline $\begin{array}{l}\text { Byli po } \\
\text { rozwodzie }\end{array}$ & 3 & 6 & 28 & 4 & 41 \\
\hline $\begin{array}{l}\text { Nigdy nie byli } \\
\text { malżeństwem }\end{array}$ & 0 & 1 & 10 & 2 & 13 \\
\hline $\begin{array}{l}\text { Nie dotyczy } \\
\text { (np. jedno zmarto, } \\
\text { ojcostwa nie ustalono) }\end{array}$ & nie dot. & 3 & 20 & 4 & 27 \\
\hline Ogółem & 99 & 14 & 73 & 14 & 200 \\
\hline \multicolumn{6}{|c|}{ w odsetkach } \\
\hline Byli matżeństwem & 48 & 2 & 7,5 & 2 & 59,5 \\
\hline $\begin{array}{l}\text { Byli po } \\
\text { rozwodzie }\end{array}$ & 1,5 & 3 & 14 & 2 & 20,5 \\
\hline $\begin{array}{l}\text { Nigdy nie byli } \\
\text { matżeństwem }\end{array}$ & 0 & 0,5 & 5 & 1 & 6,5 \\
\hline $\begin{array}{l}\text { Nie dotyczy } \\
\text { (np. jedno zmarto, } \\
\text { ojcostwa nie ustalono) }\end{array}$ & nie dot. & 1,5 & 10 & 2 & 13,5 \\
\hline Ogółem & 49,5 & 7 & 36,5 & 7 & 100 \\
\hline
\end{tabular}

Z punktu widzenia głównego przedmiotu niniejszego opracowania, najistotniejszym elementem przeprowadzonego badania było pozyskanie informacji na temat sposobu wychowywania dzieci, które wyrządziły szkodę, przez ich rodziców. W tabeli nr 19 zestawione zostały wyniki dotyczące pozostawania rodziców w związku małżeńskim oraz zamieszkiwania $\mathrm{z}$ dzieckiem $\mathrm{w}$ chwili popełnienia przez nie czynu karalnego. Należy przy tym zaznaczyć, iż 
informacje na temat zamieszkiwania z dzieckiem (kolumny ,tylko ojciec”, „tylko matka”) dotyczą jego rodziców biologicznych i nie wykluczają związania się rodzica $z$ innym partnerem. Akta spraw sądowych nie zawierały rozbudowanych informacji na temat tej ostatniej okoliczności. Postępowanie dowodowe z reguły koncentrowało się wokół rodziców dziecka, jako osób odpowiedzialnych za jego wychowanie.

Badanie wykazało, że w mniej niż połowie zbadanych spraw, tj w 96 przypadkach $(48 \%)$ rodzice byli małżeństwem i zarazem oboje zamieszkiwali ze swoim dzieckiem. W 19 sprawach (9,5\%) rodzice byli małżeństwem, ale jedno $\mathrm{z}$ nich nie zamieszkiwało z dzieckiem. Rodzice 41 (20,5\%) nieletnich byli po rozwodzie, przy czym najliczniej w tej grupie występowała sytuacja, w której z dzieckiem zamieszkiwała matka (28 przypadków - 14\%). W 27 sprawach $(13,5 \%)$ jedno $\mathrm{z}$ rodziców nie żyło lub ojcostwo nie zostało ustalone, a w $13(6,5 \%)$ rodzice nigdy nie byli małżeństwem. Nie odnotowano rodzin złożonych z partnerów (osób żyjących bez zawarcia związku małżeńskiego) będących rodzicami dziecka i z nim zamieszkujących.

W 73 przypadkach zbadanych akt sądowych $(36,5 \%)$ rodzicem, z którym zamieszkiwał nieletni była matka, natomiast w 14-tu (7\%) - ojciec. Odnotowano również 14 przypadków, w których żadne z rodziców nie zamieszkiwało ze swoim dzieckiem. Należy tu zaznaczyć, że do badań zakwalifikowano tylko te akta, w których rodzice nieletniego (przynajmniej jedno z nich) byli znani i mogli wywrzeć wpływ na jego postępowanie, nawet jeśli w chwili wyrządzenia szkody nie byli obecni.

Informacja o tym, że w ponad połowie zbadanych spraw (104 przypadki-52\%) nieletni byli pozbawieni normalnie funkcjonującej rodziny złożonej z rodziców biologicznych wymaga szczególnego podkreślenia.

Ze względu na to, że prezentowane wyniki badań aktowych wskazują na częste występowanie w badanej grupie rodzin rozbitych (rozwody, separacje faktyczne), istotne jest ustalenie przyczyn stojących u podstaw tych sytuacji. 
Wykres 5. Przyczyny rozbicia rodzin

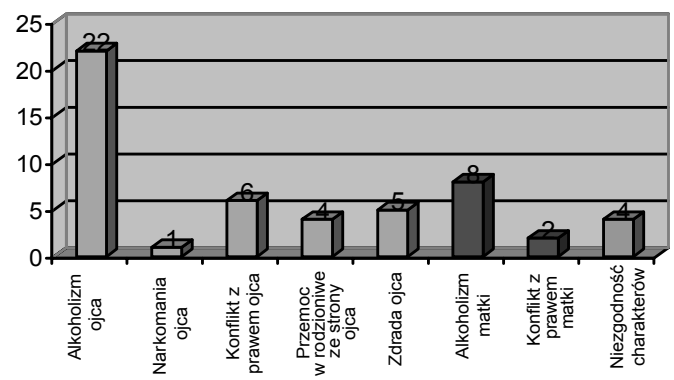

Wykres nr 5 został sporządzony na podstawie tych akt spraw, które dostarczały informacji na temat przyczyn rozbicia rodzin. Należy zatem mieć na względzie, iż w pewnej liczbie przypadków przyczyn tych nie udało się ustalić i liczba ta nie została tu uwzględniona. Odczytując dane z wykresu, należy również mieć na uwadze, że w przypadku jednej rodziny mogła istnieć więcej niż jedna przyczyna jej rozbicia. Celem prezentowania tych danych jest ukazanie proporcji pomiędzy przyczynami rozpadu rodzin w badanej grupie.

Wykres wskazuje, że z reguły przyczyny rozbicia rodziny leżały po stronie ojca, przy czym zdecydowanie najczęściej występującym czynnikiem był jego alkoholizm (22 sprawy). Wśród matek również najczęściej występującą przyczyną rozpadu rodziny był alkoholizm. Niezgodność charakterów wystapiła $\mathrm{w} 4$ przypadkach. Porównując te proporcje $\mathrm{z}$ danymi ogólnopolskimi należy zwrócić uwagę na ich odmienny rozkład. Według danych Głównego Urzędu Statystycznego ${ }^{12}$, najczęstszą przyczyną rozkładu pożycia małżeństw, które rozwiodły się w 2002 r. była niezgodność charakterów (14 428 przypadków), następnie niedochowanie wierności małżeńskiej (11 688) i dopiero na trzecim miejscu - nadużywanie alkoholu (10 241). Oczywiście należy mieć na względzie, że dane te dotyczą rozwodów, podczas gdy wyniki badania aktowego zawarte w wykresie

12 Por. baza danych na stronie internetowej GUS: http://www.stat.gov. pl/cgi_bin/demografia/xrap?woj=101\&table=web_dr\&rok=2002\&przy $1=10 \&$ win $=4$ 
nr 5 obejmują również przypadki separacji faktycznej. Niemniej rozbieżności te można thumaczyć specyfiką badanej grupy. Można domniemywać, że nieletni, którzy popadli w konflikt z prawem byli częściej narażeni na szczególnie drastyczne postacie konfliktu pomiędzy ich rodzicami, co negatywnie zaważyło na przebiegu procesu wychowawczego tych dzieci.

Tabela 21. Stan faktyczny w zakresie wykonywania przez rodziców władzy rodzicielskiej nad nieletnimi w chwili wyrzadzenia przez nich szkody.

\begin{tabular}{|c|c|c|c|c|c|c|c|}
\hline \multirow[b]{2}{*}{$\begin{array}{c}\text { Wykonywanie władzy rodzicielskiej } \\
\text { przez ojca }\end{array}$} & \multicolumn{6}{|c|}{ Wykonywanie władzy rodzicielskiej przez matkę } & \multirow[b]{2}{*}{$\frac{5}{5}$} \\
\hline & 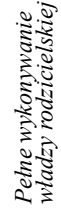 & 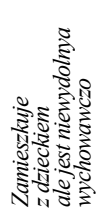 & 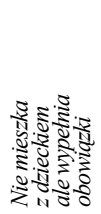 & 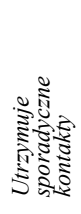 & 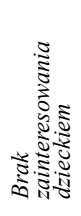 & 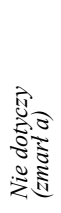 & \\
\hline \multicolumn{8}{|c|}{ w liczbach bezwzględnych } \\
\hline $\begin{array}{l}\text { Petne wykonywanie władzy } \\
\text { rodzicielskiej }\end{array}$ & 51 & 4 & 1 & 3 & 6 & 1 & 66 \\
\hline $\begin{array}{l}\text { Zamieszkuje z dzieckiem } \\
\text { ale jest niewydolny wychow. }\end{array}$ & 18 & 26 & 0 & 1 & 0 & 2 & 47 \\
\hline $\begin{array}{l}\text { Nie mieszka z dzieckiem } \\
\text { ale wypetnia obowiazki }\end{array}$ & 3 & 0 & 0 & 0 & 0 & 0 & 3 \\
\hline Utrzymuje sporadyczne kontakty & 9 & 2 & 2 & 3 & 0 & 0 & 16 \\
\hline Brak zainteresowania dzieckiem & 37 & 2 & 2 & 2 & 1 & 0 & 44 \\
\hline $\begin{array}{l}\text { Nie dotyczy (zmart lub nie ustalono } \\
\text { ojcostwa) }\end{array}$ & 18 & 2 & 0 & 0 & 0 & 4 & 24 \\
\hline Ogółem & 136 & 36 & 5 & 9 & 7 & 7 & 200 \\
\hline \multicolumn{8}{|c|}{ w odsetkach } \\
\hline $\begin{array}{l}\text { Petne wykonywanie wladzy } \\
\text { rodzicielskiej }\end{array}$ & 25,5 & 2 & 0,5 & 1,5 & 3 & 0,5 & 33 \\
\hline $\begin{array}{l}\text { Zamieszkuje z dzieckiem } \\
\text { ale jest niewydolny wychow. }\end{array}$ & 9 & 13 & 0 & 0,5 & 0 & 1 & 23,5 \\
\hline $\begin{array}{l}\text { Nie mieszka z dzieckiem } \\
\text { ale wypetnia obowiazki }\end{array}$ & 1,5 & 0 & 0 & 0 & 0 & 0 & 1,5 \\
\hline Utrzymuje sporadyczne kontakty & 4,5 & 1 & 1 & 1,5 & 0 & 0 & 8 \\
\hline Brak zainteresowania dzieckiem & 18,5 & 1 & 1 & 1 & 0,5 & 0 & 22 \\
\hline $\begin{array}{l}\text { Nie dotyczy (zmart lub nie ustalono } \\
\text { ojcostwa) }\end{array}$ & 9 & 1 & 0 & 0 & 0 & 2 & 12 \\
\hline Ogółem & 68 & 18 & 2,5 & 4,5 & 3,5 & 3,5 & 100 \\
\hline
\end{tabular}


W badaniu aktowym napotkano trudności dotyczące precyzyjnego ustalenia stanu prawnego w zakresie władzy rodzicielskiej. $\mathrm{Z}$ reguły akta spraw nieletnich nie zawierały dokładnych informacji na ten temat. Dostarczały jednak wiedzy o faktycznym wykonywaniu tej władzy przez rodziców.

Tabela nr 21 obrazuje rzeczywisty sposób wykonywania władzy rodzicielskiej we wszystkich zbadanych sprawach. Postępowanie rodziców ujęto w ramach pięciu kategorii. „Pełne wykonywanie władzy rodzicielskiej” oznaczało przede wszystkim zamieszkiwanie z dzieckiem i wykonywanie bieżącej pieczy oraz brak w aktach sprawy wzmianki o nienależytym wykonywaniu władzy rodzicielskiej. Należy mieć na uwadze, że akta spraw sądowych zazwyczaj nie dostarczają informacji o takim stopniu szczegółowości, który pozwoliłby na wychwycenie wszelkich błędów wychowawczych rodziców i to nawet w przypadku przeprowadzenia dowodu z opinii Rodzinnego Ośrodka Diagnostyczno-Konsultacyjnego czy opinii biegłego psychologa. Jednakże w kategorii tej znaleźli się rodzice, o których - na podstawie badanych akt sądowych - można było powiedzieć, że wykazują zainteresowanie i troskę o swoje dziecko. W kategorii „Zamieszkuje z dzieckiem, ale jest niewydolny wychowawczo" znaleźli się rodzice, którzy pomimo zamieszkiwania z dzieckiem zaniedbywali je, byli nieporadni wychowawczo, dopuszczali się przemocy, popadli w konflikt z prawem, chorobę alkoholową itp., a więc ich postępowanie drastycznie naruszało dobro dziecka. Pozostałe trzy modele postępowania obejmowały sytuacje, $w$ których rodzic $z$ dzieckiem nie zamieszkiwał. Wyróżniono tu przypadki, w których rodzice wykazywali zainteresowanie dzieckiem, utrzymywali sporadyczne kontakty, bądź w ogóle się nim nie interesowali.

Przechodząc do analizy uzyskanych wyników należy podkreślić, że w zaledwie ok. $1 / 4$ zbadanych spraw (51 przypadków - 25,5\%) władza rodzicielska wykonywana była przez oboje rodziców zamieszkujących z dzieckiem w sposób pełny. Oznacza to, że w pozostałych 149 przypadkach $(74,5 \%)$ proces wychowawczy podlegał z różnych przyczyn istotnemu zaburzeniu. W 37 sprawach (18,5\%) władza rodzicielska była wykonywana przez matkę przy braku jakiegokolwiek zainteresowa- 
nia dzieckiem ze strony ojca. Była to druga co do wielkości grupa przypadków. Trzecią stanowiły sprawy, w których zarówno ojciec jak i matka zamieszkiwali z dzieckiem, ale byli niewydolni wychowawczo - 26 nieletnich (13\%). Swoje obowiązki wobec dziecka w pełnym zakresie wykonywało 136 matek i 66 ojców. Dysproporcja ta widoczna była również wśród rodziców zaniedbujących swoje dzieci. Odnotowano 44 przypadki ojców nie utrzymujących kontaktów z dzieckiem i jedynie 7 matek postępujących w ten sposób. Jak już wcześniej wspomniano stosunkowo liczną grupę nieletnich stanowili ci, których ojcowie zmarli (23 przypadki - por. tab. 17). Liczba $24 \mathrm{w}$ tabeli nr $21 \mathrm{w}$ kategorii ,Nie dotyczy (zmarł lub ojcostwa nie ustalono)" oznacza zatem, iż ojcostwo nie było ustalone w jednym przypadku.

Zaprezentowane wyniki wykazują związek między różnymi formami zaniedbywania wychowania dziecka przez rodziców, a jego postępowaniem, co wymaga tutaj wyraźnego podkreślenia w kontekście zasadniczego przedmiotu niniejszego opracowania.

Dotychczas poddawano analizie poszczególne fakty dotyczące nieletnich. Na zakończenie tej części należy jeszcze dokonać zestawienia, które udzieli odpowiedzi na pytanie, w ilu sprawach nieletni wychowywali się w prawidłowo funkcjonującej rodzinie i środowisku, nie sprawiając kłopotów wychowawczych, a w ilu tak nie było. Celem ukazania wzajemnych proporcji dane te zostaną przedstawione w formie wykresu.

Wykres 6. Sytuacja nieletnich przed popetnieniem przez nich czynu karalnego
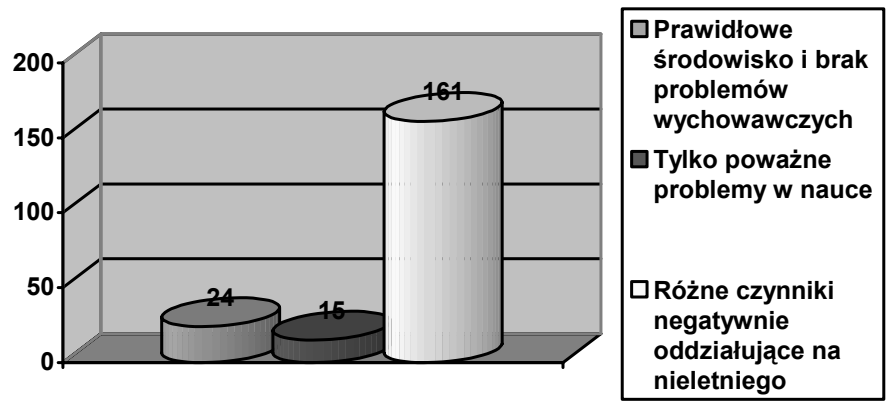
Wykres nr 6 przedstawia trzy kategorie spraw. W pierwszej („Prawidłowe środowisko i brak problemów wychowawczych”) znaleźli się ci nieletni, co do których na podstawie akt sądowych można było przypuszczać, że wychowywali się w pełnych i prawidłowo funkcjonujących rodzinach, bez elementów patologii oraz że nie sprawiali poważnych problemów wychowawczych przed wyrządzeniem szkody. Odnotowano zaledwie 24 takie przypadki, co stanowiło 12\% ogółu zbadanych spraw. Do drugiej kategorii (,,Tylko poważne problemy w nauce") zaliczono nieletnich w podobnej sytuacji jak w kategorii pierwszej, ale napotykających na poważne trudności w nauce. Kategorię tę wyodrębniono, ponieważ trudności w nauce nie muszą świadczyć o nienależytym wykonywaniu obowiązków przez rodziców, natomiast przy dużym natężeniu (a takie sytuacje brano tu pod uwagę - przede wszystkim powtarzanie klas) powinny stanowić dla rodziców ostrzeżenie o zagrożeniu przebiegu procesu wychowawczego ich dziecka. Odnotowano 15 takich przypadków (7,5\%). W trzeciej kategorii (,Różne czynniki negatywnie oddziałujące na dziecko”) znaleźli się wszyscy ci nieletni, w których przypadku wystapił przynajmniej jeden z takich czynników jak: rozbicie rodziny, wychowywanie się w rodzinie niepełnej spowodowane innymi przyczynami, patologie w rodzinie, poważne kłopoty wychowawcze, wpływ środowiska patologicznego spoza rodziny, uprzednie popełnianie czynów karalnych. Odnotowano tu aż 161 spraw nieletnich $(80,5 \%)$. Wynik ten można interpretować w ten sposób, że w ponad $80 \%$ spraw nieletnich, jeszcze przed popełnieniem czynu karalnego istniały pewne symptomy zwiększające prawdopodobieństwo wyrządzenia szkody przez nieletniego, a więc nakładające na rodziców (rodzica) obowiązek szczególnej dbałości o wychowanie dziecka. Możliwość uprzedniego zaobserwowania tych symptomów w większości przypadków wyrządzenia szkody przez dziecko ma duże znaczenie dla oceny odpowiedzialności rodziców za tę szkodę.

\section{CZYNY KARALNE NIELETNICH - WYRZĄDZONA SZKODA}

Jak już wspomniano na wstępie, badaniem objęto te akta spraw nieletnich, które dotyczyły popełnienia czynów karalnych równoznacz- 
nych z wyrządzeniem szkody. Oprócz takich czynów jak uszkodzenie rzeczy, uszkodzenie ciała, czy kradzież z włamaniem, wyrządzenie szkody mogło nastapić również w przypadku przestępstw kradzieży, czy rozboju. Tego typu czyny stanowią najbardziej pospolity rodzaj zdarzeń objętych trybem postępowania $\mathrm{w}$ sprawach nieletnich. W tym przypadku nie były kwalifikowane do badania te sprawy, w których nieletni dopuścili się np. usiłowania kradzieży, bądź zostali złapani na gorącym uczynku, a co za tym idzie przedmiot kradzieży został odzyskany od razu i nie można było mówić o powstaniu szkody cywilnej. Często jednak przedmiot ten był przez nieletnich sprzedany, a pieniądze uzyskane ze skradzionych przedmiotów wydane. Istniały zatem przesłanki do zakwalifikowania tych akt do badania.

Tabela 22. Czyny karalne popetnione przez nieletnich*

\begin{tabular}{|l|c|c|}
\hline \multirow{2}{*}{ Rodzaj popetnionego czynu } & \multicolumn{2}{|c|}{ Liczba przypadków } \\
\cline { 2 - 3 } & w liczbach bezwzgl. & wodsetkach \\
\hline Uszkodzenie rzeczy & 43 & 21,5 \\
Uszkodzenie ciała & 53 & 26,5 \\
Kradzié̇ & 85 & 42,5 \\
Kradzież z włamaniem & 10 & 5 \\
Rozbój & 39 & 19,5 \\
Oszustwo & 1 & 0,5 \\
Wywołanie alarmu bombowego & 1 & 0,5 \\
\hline
\end{tabular}

* jeden nieletni mógt popetnić więcej niż jeden czyn karalny

$\mathrm{W}$ tabeli $\mathrm{nr} 22$ przedstawiono rodzaj popełnianych przez nieletnich czynów karalnych. W niektórych przypadkach przedmiotem postępowania było popełnienie więcej niż jednego rodzaju czynów karalnych i dlatego ogólna ich liczba przekracza liczbę zbadanych spraw. (w 23 sprawach nieletni popełnili 2 czyny, w $3-3$ i w $1-4$ ). W zdecydowanej większości (173) sprawa toczyła się ze względu na popełnienie jednego czynu.

W przeprowadzonym badaniu - pomimo odrzucenia części przypadków z przyczyn opisanych wyżej - nieletni najczęściej popełniali kradzieże ( 85 spraw, co stanowiło $42,5 \%$ ). Szkoda wynikająca z uszkodzenia ciała wystapiła w 53 przypadkach $(26,5 \%)$, a z uszkodzenia rze- 
czy - w 43 (21,5\%). W jednej sprawie nieletni dopuścił się oszustwa i w jednej spowodował szkodę, wywołując alarm bombowy.

Nieletni dopuszczali się czynów odpowiadających pospolitym przestępstwom. Oprócz kradzieży, zdarzenia powodujące wszczęcie postępowania w trybie ustawy o postępowaniu w sprawach nieletnich były najczęściej związane z uczestniczeniem w bójkach (uszkodzenia ciała) bądź aktach wandalizmu (zniszczenia rzeczy), takich jak np. niszczenie ścian poprzez malowanie grafitti. Lektura akt sądowych pozwalała określić pewne rodzaje czynów karalnych jako typowe nie tylko co do ich znamion wskazanych w Kodeksie karnym, ale i co do przedmiotu. Tak np. jako nagminnie występujący przypadek można wskazać kradzież rowerów. W jednej ze spraw nieletni dopuścił się 25 takich kradzieży.

Należy zauważyć, że nie odnotowano popełnienia czynów opisanych w rozdziale XXV Kodeksu karnego „Przestępstwa przeciwko wolności seksualnej i obyczajności”.

Tabela 23. Wysokość szkód wyrzqdzonych przez nieletnich

\begin{tabular}{|l|c|c|}
\hline \multirow{2}{*}{ Wysokość szkody } & \multicolumn{2}{|c|}{ liczba spraw } \\
\cline { 2 - 3 } & w liczbach bezwzgl. & w odsetkach \\
\hline Do 499,99 zł & 38 & 19 \\
500 do 999,99 zł & 44 & 22 \\
1000 do 1999,99 zł & 32 & 16 \\
2000 do 4999,99 zł & 25 & 12,5 \\
5000 do 9999,99 zł & 8 & 4 \\
Powyżej 10000 zł & 7 & 3,5 \\
Nie wynikało z akt & 46 & 23 \\
\hline Razem & 200 & 100 \\
\hline
\end{tabular}

Odnosząc się do danych zawartych w tabeli nr 23, należy przede wszystkim wskazać na stosunkowo wysoką liczbę spraw, w których na podstawie akt nie można było oszacować wysokości wyrządzonej szkody (46 przypadków, tj 23\% ogółu zbadanych akt). Z sytuacją taką można się było spotkać niemal we wszystkich sprawach, w których doszło do wyrządzenia szkody na osobie. Wynikało to zapewne z podejmowania leczenia w placówkach publicznej służby 
zdrowia z wykorzystaniem ubezpieczenia zdrowotnego. Informacje określające wymiar szkody na osobie w pieniądzach pojawiały się w nielicznych sprawach, w których doszło np. do skorzystania z usług prywatnych lekarzy w zakresie pomocy dentystycznej. Nie odnotowano zgłaszania roszczeń z tytułu zadośćuczynienia za szkodę niemajątkową ze względu na naruszenie dóbr osobistych, a tym bardziej wyrażania tego rodzaju strat w pieniądzach. Należy mieć na uwadze, że gdyby do tego doszło, wartość szkody w tych przypadkach mieściłaby się w wyższych - spośród wyróżnionych - przedziałach.

Natomiast w pozostałych aktach spraw oszacowanie wysokości wyrządzonej szkody z reguły nie nastręczało trudności. Najczęściej jej wartość zamykała się w przedziale pomiędzy 500, a 999,99 zł (44 sprawy, tj. 22\%). W 38 sprawach nieletni wyrządzili szkodę nie przekraczającą 500 zł, a w 32 - zamykającą się pomiędzy 1000 , a 1999 zł. Najrzadziej można było spotkać zdarzenia, w których wartość szkody przekroczyła 10000 zł (7 przypadków). Najwyższa odnotowana wartość szkody majątkowej wynosiła 67000 zł.

Analiza uzyskanych wyników w aspekcie wartości wyrządzonej szkody wskazuje na to, że czyny karalne popełniane przez nieletnich nie ograniczają się do drobnych zdarzeń takich jak np. niewielkie kradzieże. Jeśli zsumować przypadki wyrządzenia szkody ponad $1000 \mathrm{zł}$, to okaże się, że było ich 72 (tj. 36\%). Ponadto - jak już wskazano - do tej liczby można dodać większość przypadków wyrządzenia szkody na osobie, ze względu na możliwość dochodzenia zarówno odszkodowania jak i zadośćuczynienia przez osobę poszkodowaną. Przytoczone dane liczbowe wskazują zatem, że zagadnienie odpowiedzialności za szkodę wyrządzoną przez dziecko jest istotnym problemem wymagającym skutecznego i funkcjonalnego rozwiązania prawnego, uwzględniającego społeczną skalę zjawiska. Problem ten występuje przede wszystkim w obrębie przestępczości nieletnich, nie zaś w odosobnionych i wyjątkowych przypadkach wyrządzenia szkody przez małe dziecko w sposób przypadkowy. 
Przechodząc do omawiania wyników badań w zakresie naprawienia wyrządzonej szkody należy w pierwszej kolejności podkreślić, że w żadnej z badanych spraw sąd nie skorzystał z instytucji służącej temu celowi, przewidzianej w ustawie o postępowaniu w sprawach nieletnich. Na pytanie zawarte w kwestionariuszu, które brzmiało: „Czy sąd zobowiązał rodziców do naprawienia w całości lub w części szkody wyrządzonej przez nieletniego (na podstawie art. $7 \S 1$ pkt 2) ustawy o postępowaniu w sprawach nieletnich)?", we wszystkich zbadanych sprawach uzyskano odpowiedź negatywną. Oznacza to, iż sądy orzekające $\mathrm{w}$ sprawach nieletnich $\mathrm{z}$ reguły nie wykazywały zainteresowania elementem naprawienia szkody. Można przypuszczać, że dzieje się tak ze względu na pozostawienie tego aspektu sprawy sądom cywilnym. Te jednak - jak wynikło z badań pilotażowych - sporadycznie zajmują się tego typu sprawami. Naprawienie szkody w ramach postępowania w sprawach nieletnich ma walor wychowawczy i dlatego do istniejącej praktyki należy odnieść się krytycznie.

W tym miejscu należy również zwrócić uwagę na brak wykorzystania przez sądy orzekające $w$ badanych sprawach jeszcze jednej instytucji zawartej w ustawie o postępowaniu w sprawach nieletnich. W żadnym ze zbadanych przypadków sąd nie skorzystał $\mathrm{z}$ przewidzianej $\mathrm{w}$ art. 3a tej ustawy możliwości skierowania sprawy do mediacji ${ }^{13}$. Jej przeprowadzenie byłoby najlepszą sposobnością do polubownego rozstrzygnięcia kwestii ewentualnych roszczeń osób poszkodowanych, z której jednak - jak się okazuje - sądy nie korzystają. Również w przypadku tej instytucji należy zwrócić uwagę na jej walor wychowawczy i de lege lata postulować jej pełniejsze wykorzystanie.

Kontekst wskazanej wyżej praktyki sądów należy mieć na uwadze przy interpretacji kolejnych wyników badań.

${ }^{13}$ Możliwość ta została expressis verbis wprowadzona do ustawy nowelą z 15 września 2000 r. (Dz.U. z 2000 r. Nr 91, poz. 1010), ale już wcześniej była dopuszczana na gruncie obowiązujących wówczas przepisów. W tym zakresie por. np. B. Czarnecka-Dzialuk, D. WóJcik, Mediacja $w$ sprawach nieletnich $w$ świetle teorii i badań, Warszawa 2001, s. 53-54. 
Tabela 24. Naprawienie szkody wyrzadzonej przez nieletnich w badanych sprawach

\begin{tabular}{|l|c|c|}
\hline \multirow{2}{*}{ Czy szkoda została } & \multicolumn{2}{|c|}{ liczba spraw } \\
\cline { 2 - 3 } & w liczbach bezwzględnych & wodsetkach \\
\hline Tak & 43 & 21,5 \\
Nie & 88 & 44 \\
Nie wynikało z akt & 69 & 34,5 \\
\hline Razem & 200 & 100 \\
\hline
\end{tabular}

Na podstawie lektury badanych akt sądowych w 88 sprawach można było wnioskować, że szkoda wyrządzona przez nieletniego nie została naprawiona. Aż w 69 przypadkach akta spraw nie dawały podstaw do kategorycznego stwierdzenia faktu naprawienia szkody bądź zaniechania naprawienia szkody. Wynikało to - jak można przypuszczać - z opisanego wyżej braku zainteresowania sądów tymi kwestiami. Można jednak z dużym prawdopodobieństwem stwierdzić, że w niemal wszystkich tych przypadkach szkoda nie została naprawiona. Naprawienie szkody oznacza poniesienie konsekwencji swojego nagannego zachowania przez nieletniego. Powołanie się na taki fakt przed sądem jest więc dla nieletniego korzystne i gdyby miało miejsce, zostałoby odnotowane w aktach sprawy.

Pozytywna informacja dotycząca naprawienia szkody znalazła w 43 sprawach $(21,5 \%)$.

Tabela 25. Sposób naprawienia szkody oraz podmiot, który tego dokonat

\begin{tabular}{|l|c|c|c|c|c|}
\hline \multirow{2}{*}{$\begin{array}{l}\text { Pomiot który } \\
\text { naprawit } \\
\text { szkodę }\end{array}$} & $\begin{array}{l}\text { zaptata kwoty } \\
\text { pieniężej }\end{array}$ & $\begin{array}{l}\text { zwrot } \\
\text { rzeczy }\end{array}$ & $\begin{array}{l}\text { wykonanie } \\
\text { pracy na poczet } \\
\text { naprawienia szkody }\end{array}$ & $\begin{array}{l}\text { naprawienie } \\
\text { rzeczy }\end{array}$ & $\begin{array}{l}\text { wyptata } \\
\text { z polisy } \\
\text { OC }\end{array}$ \\
\hline \multicolumn{7}{|c|}{ w liczbach bezwzględnych } \\
\hline Rodzice & 4 & 0 & 0 & 0 & 1 \\
\hline Nieletni & 1 & 25 & 1 & 3 & 0 \\
\hline Policja* & nie dot. & 8 & nie dot. & nie dot. & nie dot. \\
\hline \multicolumn{7}{|c|}{ wodsetkach } \\
\hline Rodzice & 2 & 0 & 0 & 0 & 0,5 \\
\hline Nieletni & 0,5 & 12,5 & 0,5 & 1,5 & 0 \\
\hline Policja* & nie dot. & 4 & nie dot. & nie dot. & nie dot. \\
\hline
\end{tabular}

* przedmiot został odzyskany przez Policje 
Z powyższej tabeli wynika że, większość przypadków naprawienia szkody miała miejsce wtedy, gdy było to najłatwiejsze $\mathrm{i}$ w pewien sposób wymuszone na nieletnim. W 25 sprawach szkoda została naprawiona przez zwrot rzeczy wtedy, gdy znajdowała się ona jeszcze w posiadaniu nieletniego. W 8 przypadkach rzecz została odzyskana przez Policję w ramach prowadzonego śledztwa. Jedynie w 4 sprawach nastapiło naprawienie szkody poprzez zapłatę kwoty pieniężnej przez rodziców. W 3 sprawach sam nieletni dokonał naprawy uszkodzonej rzeczy, a w jednej wypłata odszkodowania nastąpiła z polisy odpowiedzialności cywilnej. Również w jednej sprawie nieletni wykonał pracę na poczet naprawienia szkody.

Uwagę zwraca znikome - gdy chodzi o częstotliwość - wykorzystanie form naprawienia szkody najkorzystniejszych dla nieletniego pod względem wychowawczym, tj. wykonania pracy na poczet naprawienia szkody bądź naprawienia zniszczonej rzeczy (np. w razie zniszczenia murów budynku przez malowanie graffiti). Należy postulować częstsze ich wykorzystanie.

Analizę wyników badań uzupełnia wskazanie rodzaju poszkodowanego podmiotu, tj określenie czy była nim osoba fizyczna czy też osoba prawna.

Wykres 7. Rodzaj poszkodowanego podmiotu $w$ badanych sprawach
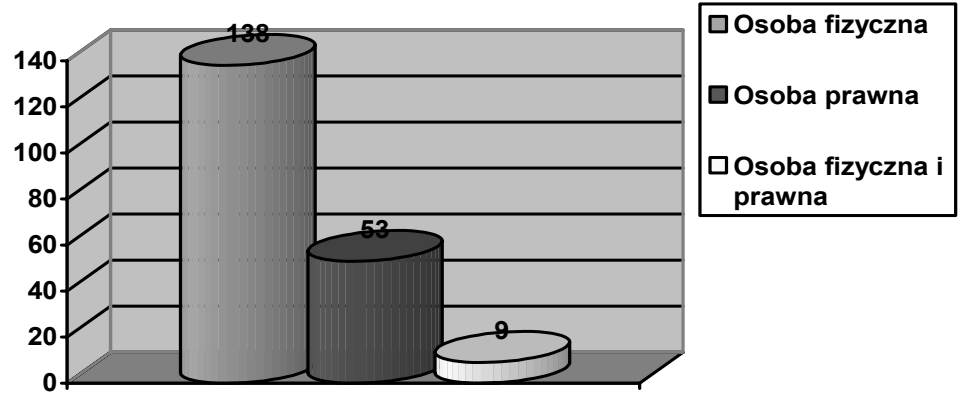

W 138 sprawach poszkodowanym była osoba fizyczna, w 53 - osoba prawna. W 9 sprawach nieletni wyrządził szkodę zarówno osobie fizycznej jak i prawnej. 


\section{PostęPoWANIE DOWODOWE ORAZ ZASTOSOWANE WOBEC NIELETNICH ŚRODKI WYCHOWAWCZE LUB POPRAWCZE PRZEWIDZIANE W USTAWIE O POSTĘPOWANIU W SPRAWACH NIELETNICH}

W ramach badania akt sądowych ustalono również sposób prowadzenia przez sąd postępowania dowodowego. Jakkolwiek Informacje te nie wiążą się w sposób bezpośredni z problemem odpowiedzialności odszkodowawczej rodziców, to jednak pozwalają ocenić wnikliwość sądu w zakresie badania sytuacji rodzinnej i przebiegu procesu wychowawczego nieletnich. W tabeli nr 26 zawarto wykaz dowodów, którymi posługiwały się sądy i które pozwoliły dokonać ustaleń w tym zakresie. Pominięto natomiast zawarte w aktach notatki i protokoły policyjne.

Tabela 26. Dowody przeprowadzone przez sqd*

\begin{tabular}{|l|c|c|}
\hline \multirow{2}{*}{ Rodzaj dopuszczonego dowodu } & \multicolumn{2}{|c|}{ Liczba spraw } \\
\cline { 2 - 3 } & w liczbach bezwzlędnych & w odsetkach \\
\hline Zeznania świadków & 200 & 100 \\
Wywiad środowiskowy przeprowadzony & 187 & 93,5 \\
przez kuratora & & \\
Opinia Rodzinnego Ośrodka & 52 & 26 \\
Diagnostyczno - Konsultacyjnego & 16 & 8 \\
Opinia ze szkoty nieletniego & 11 & 5,5 \\
Opinia biegłego psychologa & 3 & 1,5 \\
Opinia biegłego psychiatry & 1 & 0,5 \\
Opinia lekarska & 8 & 4 \\
Opinia Pogotowia Opiekuńczego & 2 & 1 \\
Opinia placówki & & 1,5 \\
resocjalizacyjno-wychowawczej & 7 & 3,5 \\
Opinia ośrodka szkolno & 1 & 0,5 \\
- wychowawczego & 2 & 1 \\
Opinia ośrodka leczenia uzależnień & 3 & \\
Opinia zakładu poprawczego & & \\
Opinia kuratora zawodowego & & \\
\hline
\end{tabular}

* w jednej sprawie mogło być przeprowadzonych kilka dowodów 
We wszystkich sprawach sądy dopuściły dowód z przesłuchania świadków. W 187 sprawach (93,5\%), a więc niemal we wszystkich, dopuszczony został również dowód $\mathrm{z}$ wywiadu środowiskowego przeprowadzonego przez kuratora. Można powiedzieć, że te dwa dowody stanowiły w zbadanych przypadkach pewien standard wyznaczający postępowanie sądu. Przede wszystkim na ich podstawie sądy podejmowały decyzje.

W 52 sprawach (26\%), a więc w nieco ponad jednej czwartej zbadanych przypadków został dopuszczony dowód z opinii Rodzinnego Ośrodka Diagnostyczno - Konsultacyjnego. W tym miejscu warto poczynić kilka uwag odnośnie tego dowodu. Zebrane doświadczenia podczas prowadzenia analizy akt sądowych i wypełniania kwestionariuszy nakazują ocenić dowód z opinii Rodzinnego Ośrodka Diagnostyczno - Konsultacyjnego zdecydowanie najwyżej. Uporządkowana forma tej opinii i profesjonalizm jej sporządzenia gwarantowały uzyskanie potrzebnych informacji na temat sytuacji nieletniego. Oprócz wiedzy specjalistycznej, opinie te zawierały również komplet informacji, które były przedmiotem dowodu $\mathrm{z}$ wywiadu środowiskowego. Porównując te dwa dowody należy jednak nadmienić, że sporząadzane przez kuratorów - najczęściej w formie odręcznych notatek - wywiady środowiskowe często były niepełne i nie gwarantowały uzyskania potrzebnych informacji. W zakresie oceny dowodu z opinii RODK można zatem w pełni podzielić pozytywną jego ocenę wyrażoną przez W. Stojanowską w odniesieniu do spraw rozwodowych ${ }^{14}$, a co za tym idzie postulować częstsze jego wykorzystanie. Postulat ten powinien być przy tym kierowany do poszczególnych wydziałów sądów i sędziów, ponieważ częstotliwość wykorzystania dowodu z opinii RODK zależała właśnie od praktyki przyjętej w danym sądzie.

Pozostałe dowody mające na celu określenie sytuacji nieletniego występowały znacznie rzadziej. W tej grupie - pod względem ilościowym można wyróżnić dowód z opinii wystawionej przez szkołę nieletniego (16 przypadków) i dowód z opinii biegłego psychologa (11 spraw). W jednej

${ }^{14}$ Por. W. Stojanowska, Dowód z opinii rodzinnego ośrodka diagnostycznokonsultacyjnego w sprawach o rozwód i jego wplyw na treść wyroku w świetle wyników badań aktowych, «Zeszyty Prawnicze [UKSW]» 2.1 (2002), s. 51. 
sprawie został przeprowadzony dowód z opinii ośrodka leczenia uzależnień. Również w jednych aktach spraw znalazła się opinia lekarska na temat nieletniego sprawcy czynu karalnego.

Z tabeli nr 26 wynika zatem, że sposób prowadzenia postępowania dowodowego przez sądy jest podobny (dowody z przesłuchania świadków i wywiadu środowiskowego), a różnice sprowadzają się do dopuszczenia bądź rezygnacji z dowodu z opinii RODK. Pozostałe dowody mają charakter epizodyczny, tzn. występują w zależności od szczególnych okoliczności danej sprawy (np. uzależnienie nieletniego od narkotyków uzasadnia przeprowadzenie dowodu z opinii ośrodka leczenia uzależnień).

W tabeli nr 27 przedstawiono zastosowane przez sądy środki wychowawcze i poprawcze.

Tabela 27. Środki wychowawcze i poprawcze zastosowane przez sqdy* w badanych sprawach

\begin{tabular}{|c|c|c|}
\hline \multirow[b]{2}{*}{ Rodzaj środka } & \multicolumn{2}{|c|}{ Liczba spraw } \\
\hline & $\begin{array}{c}\text { w liczbach } \\
\text { bezwzględnych }\end{array}$ & wodsetkach \\
\hline Upomnienie & 27 & 13,5 \\
\hline Nadzór odpowiedzialny rodziców & 32 & 16 \\
\hline Nadzór kuratora & 86 & 43 \\
\hline $\begin{array}{l}\text { Zobowiqzanie do określonego postępowania lub } \\
\text { wykonania prac }\end{array}$ & 13 & 6,5 \\
\hline $\begin{array}{l}\text { Umieszczenie w ośrodku szkolno } \\
\text { - wychowawczym }\end{array}$ & 22 & 11 \\
\hline $\begin{array}{l}\text { Skierowanie do instytucji zajmujacej sie praca } \\
\text { z nieletnimi o charakterze wychowawczym }\end{array}$ & 3 & 1,5 \\
\hline $\begin{array}{l}\text { Zobowiqzanie rodziców do wspótpracy } \\
\text { z psychologiem }\end{array}$ & 1 & 0,5 \\
\hline $\begin{array}{l}\text { Umieszczenie w zaktadzie poprawczym (w } \\
\text { zawieszeniu) }\end{array}$ & 21 & 10,5 \\
\hline Umieszczenie w zakładzie poprawczym & 11 & 5,5 \\
\hline $\begin{array}{l}\text { Umorzenie postepowania ze względu } \\
\text { na stosowanie innych środków wychowawczych } \\
\text { (art. } 21 \oint 2 \text { u.p.n.) }\end{array}$ & 13 & 6,5 \\
\hline
\end{tabular}

* $w$ stosunku do jednego nieletniego mógł być orzeczony więcej niż jeden środek 
Uzyskane wyniki potwierdzają tendencję, która została zarysowana w tabeli $\mathrm{nr} 13$, zawierającej informacje dotyczące nieletnich którzy w przeszłości popełnili już czyny karalne. W zbadanych sprawach sądy najchętniej korzystały ze środka wychowawczego w postaci nadzoru kuratora nad nieletnim. Środek ten w sposób zdecydowany wyróżniał się pod względem częstotliwości stosowania spośród pozostałych. Został wykorzystany w 86 sprawach (43\% wszystkich zbadanych przypadków). Inne środki występowały znacznie rzadziej. Nadzór odpowiedzialny rodziców został orzeczony w 32 sprawach (16\%). W 27 przypadkach sąd upomniał nieletniego.

Zaledwie w 13 sprawach sąd zobowiązał nieletniego do określonego postępowania lub wykonania pracy. Liczba ta świadczy o pewnym oporze sądów przed stosowaniem tego środka. Wymaga on aktywnej roli sądu i pewnej jego inwencji. Jest jednak zdecydowanie korzystniejszy dla nieletnich gdy chodzi o ich wychowywanie i może również pełnić funkcję odszkodowawcza, gdy praca jest wykonywana przez nieletniego na poczet naprawienia wyrządzonej szkody ${ }^{15}$. Nadzór kuratora może wtedy pełnić funkcję pomocniczą i dyscyplinująca, tymczasem - jak wynika z badań - sądy wychodzą z założenia, że samo orzeczenie nadzoru kuratora jako jedynego środka będzie w pełni skuteczne wychowawczo. De lege lata należałoby zatem postulować szersze wykorzystanie środka wychowawczego w postaci nakazu określonego postępowania lub wykonania $\operatorname{prac}^{16}$.

Odnosząc się do zbadanych spraw sądowych, należy nadmienić, iż sądy stosując środek przewidziany w art. 6 pkt. 2) u.p.n. zobowiązywały $\mathrm{z}$ reguły nieletnich do określonego postępowania nakazując im np. poprawienie wyników w nauce bądź powstrzymanie się od przebywania $\mathrm{w}$ określonym środowisku. Wskazany przepis expressis verbis

${ }^{15}$ Por. K. Gromek, Komentarz do ustawy o postępowaniu w sprawach nieletnich, Warszawa 2004, s. 110. Autorka ocenia jako bardzo pożądane wychowawczo nakazanie nieletniemu przez sąd wykonania określonych prac w celu przywrócenia stanu poprzedniego i naprawienia w ten sposób wyrządzonej szkody.

${ }^{16}$ Podobne stanowisko zajęła K. GromeK, Komentarz do ustawy o postępowaniu w sprawach nieletnich, Warszawa 2004, s. 110. 
mówi o możliwości zobowiązania nieletniego przez sąd do naprawienia wyrządzonej szkody, jednakże przeprowadzone badanie nie wykazało ani jednego przypadku, w którym sąd nakazałby wprost takie postępowanie ${ }^{17}$. Potwierdza to wcześniejsze ustalenie braku zainteresowania sądów kwestiami związanymi z naprawieniem szkody.

W 32 sprawach zostało zastosowane umieszczenie nieletniego w zakładzie poprawczym, przy czym w większości przypadków (21) środek ten był orzeczony w zawieszeniu.

\section{OCENA BADANYCH SPRAW DOKONANA PRZEZ AUTORA BADAŃ ${ }^{18}$}

Ostatnia część ankiety została skonstruowana w taki sposób, aby możliwe było dokonanie własnej oceny stanu faktycznego danej sprawy przez prowadzącego badanie tak, aby wskazać osoby współodpowiedzialne za zaistniałą sytuację. Głównym celem spraw toczących się $\mathrm{w}$ trybie ustawy o postępowaniu w sprawach nieletnich nie jest jednak określenie odpowiedzialności rodziców, co oznacza, że materiał dowodowy nie jest zbierany w tym celu. Co więcej, w zasadzie tylko niektóre dowody, a w szczególności dowód z opinii Rodzinnego Ośrodka Diagnostyczno - Konsultacyjnego, pozwalały na odpowiednio głębokie wniknięcie w sytuację rodziny, umożliwiające sformułowanie wniosków. Dlatego w większości spraw nie można było postawić bezdyskusyjnej diagnozy przypisującej rodzicom nieletniego winę za zachowanie ich dziecka.

Pomimo tych zastrzeżeń ustalono, iż aż w 92 sprawach istniały poważne przesłanki do przypisania rodzicom winy za doprowadzenie nieletniego do popełnienia czynu objętego postępowaniem. Chodziło przy tym o zaniedbania rodziców o charakterze wychowawczym, a nie konkretne zachowanie związane ściśle $\mathrm{z}$ danym czynem karalnym.

${ }^{17}$ Informacje zawarte w tabeli nr 25 dotyczą przypadków naprawienia szkody $\mathrm{z}$ inicjatywy nieletniego bądź jego rodziców, nie zaś w ramach wykonania decyzji sądu.

${ }^{18}$ Autora niniejszego opracowania. 
Tabela 28. Sprawy, w których rodzice ponosili główna odpowiedzialność za doprowadzenie nieletniego do popetnienia czynu karalnego

\begin{tabular}{|l|c|c|}
\hline \multirow{2}{*}{$\begin{array}{l}\text { Rodzic(e) który(rzy) ponosit(li) głównq } \\
\text { odpowiedzialność za doprowadzenie } \\
\text { nieletniego do popetnienia czynu karalnego } \\
\text { objętego postępowaniem }\end{array}$} & $\begin{array}{c}\text { Liczba spraw } \\
\text { bezwzolędnych }\end{array}$ & wodsetkach \\
\cline { 2 - 3 } Matka & 10 & 5 \\
Ojciec & 24 & 12 \\
Matka i ojciec & 58 & 29 \\
Nie wynikało z akt & 108 & 54 \\
\hline Ogółem & 200 & 100 \\
\hline
\end{tabular}

Najczęściej winę można było przypisać obojgu rodzicom. Sytuacja taka wystąpiła w 58 sprawach, tj. w 29\% ogółu zbadanych akt. Ojcu można było przypisać winę w 24 sprawach, a matce $-\mathrm{w} 10$.

W ramach dokonanej analizy wskazano również rodzaj czynników, które w ocenie prowadzącego badanie doprowadziły do popełnienia przez nieletniego czynu objętego postępowaniem oraz osobę rodzica, który był źródłem tych czynników. Dane zawarte w tabeli nr 29 uzupełniają wcześniej prezentowane informacje na temat patologicznego wpływu na nieletnich (Tabela 10) oraz stanu faktycznego w zakresie wykonywania władzy rodzicielskiej przez rodziców (Tabela 21). Dotyczą one wyodrębnionej wyżej grupy 92 nieletnich. 
Tabela 29. Nieletni wedtug rodzaju czynnika negatywnie oddziatywujacego na ich wychowanie oraz osoby rodzica, który byt źródtem tego oddzialywania*

\begin{tabular}{|l|c|c|c|c|}
\hline \multirow{2}{*}{ Rodzaj czynnika } & \multicolumn{4}{|c|}{ Rodzic odpowiedzialny za dany czynnik } \\
\cline { 2 - 5 } & matka & ojciec & matka & ojciec \\
\cline { 2 - 5 } & w liczbach bezwzględnych & \multicolumn{2}{|c|}{ wodsetkach } \\
\hline Brak zainteresowania & 16 & 44 & 8 & 22 \\
dzieckiem & & & & \\
Konflikt z drugim & 4 & 8 & 2 & 4 \\
rodzicem & 12 & 34 & 6 & 17 \\
Alkoholizm & 49 & 22 & 24,5 & 11 \\
Nieporadność & 2 & 6 & 1 & 3 \\
wychowawcza & 0 & 5 & 0 & 2,5 \\
Konflikt z prawem & 4 & 3 & 2 & 1,5 \\
Stosowanie przemocy & 0 & 1 & 0 & 0,5 \\
Problemy psychiczne & & & & \\
Narkomania & & & & \\
\hline
\end{tabular}

* w jednej sprawie mogło być więcej czynników niż jeden

Powyższa tabela potwierdza wcześniej prezentowane dane. Głównym problemem dotyczącym ojców $\mathrm{w}$ ramach przeprowadzonego badania był brak zainteresowania dzieckiem z ich strony. Jako przyczyna sytuacji, w której nieletni popełnił czyn objęty postępowaniem sądowym, brak zainteresowania dzieckiem ze strony ojca wystapił w 44 sprawach ( $22 \%$ wszystkich zbadanych akt). Ze strony matek największym problemem była nieporadność wychowawcza, którą odnotowano w 49 przypadkach $(24,5 \%)$. Chodziło tu o sytuacje, w których rodzic nie wykazując innych dysfunkcji ani patologii, takich jak np. alkoholizm, nie potrafił znaleźć adekwatnych do sytuacji dziecka środków wychowawczych. Spośród problemów wyróżniających się pod względem ilościowym należy jeszcze wymienić alkoholizm, który jako przyczyna postępowania nieletniego wystapił wśród 34 ojców i 12 matek. W badanych sprawach stwierdzono również problemy psychiczne rodziców (4 ojców i 3 matki). Najrzadziej jako przyczynę sytuacji w której nieletni wyrządził szkodę można było wskazać narkomanię rodzica (1 przypadek dotyczący ojca nieletniego). 
Tabela nr 29 dotyczyła grupy 92 spraw, w których w ocenie prowadzącego badanie możliwe było przypisanie rodzicom odpowiedzialności za doprowadzenie nieletniego do popełnienia czynu objętego postępowaniem. Nie oznacza to, że w pozostałych 108 sprawach, w każdym przypadku, nieletnim można było przypisać wyłącznie złą wolę, bez jakichkolwiek zewnętrznych przyczyn zachowania.

Tabela 30. Uwarunkowania popetnienia przez nieletnich czynów objętych postępowaniem sqdowym $w$ sprawach, $w$ których nie przypisano odpowiedzialności rodzicom za ten stan rzeczy

\begin{tabular}{|l|c|c|}
\hline \multirow{2}{*}{ Uwarunkowania czynów nieletnich } & \multicolumn{2}{|c|}{ Liczba spraw } \\
\cline { 2 - 3 } & w liczbach bezwzględnych & w odsetkach \\
\hline Śmierć ojca & 6 & 3 \\
Wpływ grupy koleżeńskiej poza & 6 & 3 \\
szkołą & 3 & 1,5 \\
Wpływ grupy koleżeńskiej w szkole & 9 & 4,5 \\
Stan zdrowia psychicznego dziecka & 1 & 0,5 \\
Wpływ rodzeństwa & 47 & 23,5 \\
Zła wola nieletniego bez przyczyn & 36 & 18 \\
zewnętrznych & & \\
Nie wynikało z akt & & \\
\hline
\end{tabular}

Należy jeszcze raz podkreślić, że informacje dotyczące zewnętrznych uwarunkowań zachowania nieletnich mogły być uzyskane jedynie w tych sprawach, w których postępowanie dowodowe zostało przeprowadzone w sposób pogłębiony, najczęściej przez dopuszczenie dowodu z opinii Rodzinnego Ośrodka Diagnostyczno-Konsultacyjnego. Należy je więc traktować jako minimum, co do którego powzięto przekonanie na podstawie badania akt. Przykładowo śmierć rodzica została uznana za przyczynę zachowania dziecka tylko wtedy, gdy wniosek taki wypływał wprost $\mathrm{z}$ opinii psychologicznej zawartej w aktach sprawy. Można przypuszczać, że w rzeczywistości uwarunkowania zachowań nieletnich były bardziej złożone w pozostałych przypadkach i zostałyby wychwycone $\mathrm{w}$ razie przeprowadzenia pogłębionych analiz psychologicznych (dowodu z opinii biegłego psychologa) we wszystkich sprawach. 
Pomimo tych zastrzeżeń wyniki badania warte są przytoczenia. Jedynie w mniej niż $1 / 4$ spraw (47 przypadków - 23,5\% ogółu spraw) można było postawić hipotezę, że wyłącznie zła wola nieletniego bez przyczyn zewnętrznych stała u podstaw popełnienia czynu karalnego. W 25 sprawach możliwe było wskazanie zewnętrznych przyczyn, które negatywnie oddziaływały na zachowanie nieletnich. Wśród nich najczęściej wystapiły problemy nieletnich o naturze psychicznej $(9$ spraw). W sześciu przypadkach na zachowaniu nieletnich zaważyła śmierć ojca. Demoralizujący wpływ rodzeństwa odnotowano w jednej sprawie. W 36 sprawach zebrany materiał dowodowy nie uprawniał do postawienia jednoznacznych wniosków w omawianej materii.

Wyniki badań uzyskane przy pomocy ostatniej części ankiety wskazują, iż nawet w sprawach nieletnich, które - jak już stwierdzono nie są prowadzone $\mathrm{w}$ celu ustalenia odpowiedzialności rodziców dziecka, możliwe jest jej dostrzeżenie i powiązanie zachowania nieletniego z jego sytuacją rodzinną i sposobem postępowania rodziców. Skala dostrzeżonych nieprawidłowości, dysfunkcji i patologii dotyczących rodziców w sprawach nieletnich jest wymowna i może stanowić podstawę rozważań nad prawnym rozwiązaniem problemu ich odpowiedzialności za szkodę wyrządzoną przez dziecko.

\section{Podsumowanie}

Na wstępie niniejszego opracowania, jako jego główny cel wskazano analizę stanu faktycznego, w którym dochodzi do wyrządzenia szkody przez dziecko, w szczególności poznanie jego sytuacji rodzinnej, okoliczności w których dochodzi do wyrządzenia szkody, ewentualnego wpływu rodziców na jej wystapienie i uwarunkowań społecznych tego zdarzenia. Badanie aktowe wykazało istnienie zróżnicowanych stanów faktycznych. Sprawcami czynów karalnych byli zarówno nieletni ze środowiska patologicznego, dzieci wychowujące się w rozbitych rodzinach, jak i te, które miały zapewnione właściwe warunki wychowania i rozwoju. W podsumowaniu warto podjąć próbę określenia najbardziej typowego stanu faktycznego dotyczącego nieletnich, na podstawie najczęściej występujących sytuacji, które zostały wskazane w ramach prezentowanych wcześniej wyników badań. 
Najczęstszymi sprawcami szkody byli chłopcy ( $86 \%$ ogółu zbadanych spraw). Najliczniejszą grupe stanowili nieletni w wieku 15 lat (32\%). Większość nieletnich miała problemy w nauce $(74 \%)$ oraz stwarzała problemy wychowawcze jeszcze przed popełnieniem czynu karalnego (62\%). Natomiast kontakt ze środowiskiem patologicznym nie występował w większości spraw (51,5\%). Również zdecydowana większość nieletnich popadła w konflikt z prawem po raz pierwszy $(73 \%)$. Rodzice nieletnich najczęściej byli w wieku między 40 a 49 lat (43\% - ojcowie i 45\% - matki). Ojcowie najczęściej posiadali wykształcenie zasadnicze zawodowe $(29,5 \%)$, a matki - średnie i policealne (32\%). Większość nieletnich posiadała rodzeństwo (76\%). Typowa sytuacja majątkowa rodzin $\mathrm{w}$ omawianym badaniu była trudna lub bardzo trudna (55\%). Jako typową można również określić sytuację, w której jedno lub żadne z rodziców nie zamieszkiwało z dzieckiem (50,5\%). Najczęściej władza rodzicielska nie była wykonywana przez rodziców w sposób właściwy i pełny $(74,5 \%)$. Zestawienie różnych czynników negatywnie oddziaływujących na wychowanie dziecka (por. wykres nr 6) pozwoliło stwierdzić, że w ogromnej większości nieletni byli narażeni na takie oddziaływanie $(80,5 \%)$.

Najczęściej popełnianym czynem była kradzież (42,5\%), a wartość szkody mieściła się zazwyczaj w przedziale pomiędzy 500, a 999,99 zł $(22 \%)$. Szkoda zwykle nie była naprawiana (44\%), a sąd stosował najczęściej środek wychowawczy w postaci nadzoru kuratora (43\%).

Powyższe zestawienie w pewnym uproszczeniu obrazuje typową sytuację, w której dochodzi do wyrządzenia szkody poprzez popełnienie czynu karalnego przez nieletniego. $Z$ prezentowanych badań wynika, że zdarzeń tych nie można $\mathrm{z}$ reguły określić jako jednorazowych wybryków nieletnich, do których doszło mimo właściwego wychowania dziecka. Przeciwnie, uwagę zwraca częste występowanie czynników zaburzających prawidłowość tego procesu, za które odpowiedzialni są rodzice. Wydaje się, że tak zarysowany kontekst sytuacji, w której najczęściej dochodzi do wyrządzenia szkody przez nieletniego powinien zostać uwzględniony $\mathrm{w}$ ramach prawnego rozwiązania tego problemu. Unormowanie prawne odpowiedzialności rodziców za szkodę wyrządzoną przez ich dziecko powinno korelować z wynikami ba- 
dań empirycznych. Jeśli wyniki te wskazują na związek przyczynowy pomiędzy działaniem rodziców a wyrządzeniem szkody przez dziecko, to również rozwiązanie prawne powinno przyjmować jako zasadę odpowiedzialność rodziców. Tymczasem ustawodawca normuje te kwestie w ramach ogólnego przepisu art. 427 k.c., odnoszącego się do szerokiej kategorii osób zobowiązanych do nadzoru i nie uwzględniającego w pełni specyfiki stosunków między rodzicami a dziećmi oraz w ramach jeszcze bardziej ogólnej formuły ogólnej odpowiedzialności deliktowej na podstawie art. 415 k.c. Wnioski odnośnie przyszłego ustawodawstwa stanowią odrębny problem, który należałoby rozważyć w specjalnie temu poświęconemu opracowaniu.

De lege lata należy postulować uwzględnienie spostrzeżeń poczynionych przy okazji prezentowania wyników badań. Jak już wcześniej wskazano, sądy orzekające w trybie ustawy o postępowaniu w sprawach nieletnich posiadają instrumenty prawne pozwalające określić sposób naprawienia szkody. Chodzi tu o unormowanie zawarte w art. $7 \S 1$ pkt. 2) u.p.n., które umożliwia przypisanie odpowiedzialności za szkodę wyrządzoną przez nieletniego rodzicom lub opiekunowi oraz środek przewidziany w art. 6 pkt. 2) u.p.n., który pozwala nakazać samemu nieletniemu naprawienie szkody bądź wykonanie określonych prac na poczet jej naprawienia. Jak wykazały prezentowane wyżej wyniki badań, z pierwszej możliwości sądy nie korzystają w ogóle, natomiast z drugiej - bardzo rzadko. Praktykę taką należy ocenić negatywnie w kontekście celów wychowawczych i resocjalizacyjnych, jakie określa ustawa o postępowaniu w sprawach nieletnich.

\section{Juvenile Delinquency in the Light of the Examination of Court Files and the Problem of Parents' Responsibility for Damages Caused by Their Children}

\section{Summary}

The article presents the results of the empirical research made by the author in family and juvenile courts. The research encompassed 200 pages 
of court files, and its aim was to obtain information on the family situation, progress in education and the behaviour of the minors who caused a damage. The achieved results allowed to evaluate the causes of their behaviour as well as draw conclusions related to binding legal regulations concerning the problem of parents' civil responsibility for the damage caused by their child. 